\title{
Apuntes para una geoeconomía mundial del hambre al comenzar el siglo XXI*
}

Jaime Bonilla -Godoy**

Resumen. Este artículo examina, desde la perspectiva de la economía política y la geografía, la naturaleza de la cuestión alimentaria mundial en el contexto y las contradiccio nes de la economía mundial actual. En un examen de las tendencias recientes y con referencia particular a las condiciones de América Latina y el Caribe, el ensayo caracteriza el momento actual como un complejo de continuidad y ruptura de las tendencias de largo plazo enraizadas en la naturaleza y cambios del modo de producción capitalista, conocidos popularmente como la globalización. Como eje central, el artículo argumenta que la profundización de la crisis de acumulación, la generalización de la pobreza y el desempleo, la ampliación del abismo en la distribución de la riqueza tanto entre distintos grupos sociales como entre países y territorios y, principalmente, el carácter de la contradicción existente entre un pequeño grupo de países que subyuga al resto del mundo, constituyen elementos que, por una parte, explican la cre ciente inseguridad alimentaria y el hambre de miles de millones de personas en el mundo; $y$, por la otra, son la base para comprender -y eventualmente resolver-las contradicciones que subyacen la relación producción -ingreso consumo de alimentos, tanto entre países y regiones como al interior de los países, a comienzos del siglo XXI. Palabras clave: inseguridad alimentaria, globalización, imperialismo, neoliberalismo, espacialidad de la acumulación, comercio internacional, economía política, geografía, biodiversidad, desarrollo tecnológico, recursos genéticos, multinacionales, hambre, pobreza.

* Artículo basado en ponencia del mismo autor presentada ante el $\mathrm{V}$ Congreso sobre Biodiversidad, Bioética y Derecho, realizado en la Universidad Nacional de Colombia, Bogotá, septiembre 25 al 29 de 2000.

** Profesor de Geografía, Universidad Nacional de Colombia. El autor puede contactarse directamente en la Universidad Nacional de Colombia, Sede Bogotá, o a través de la dirección electrónica (jbonilla@dnic.unal.edu.co). 


\section{Introducción}

La cuestión de la inseguridad alimentaria mundial, su relación con la economía política, la geografía política y el análisis de recursos (entre ellos los de la biodiversidad) requiere abordarse desde una perspectiva de totalidad que tenga en cuenta los complejos de problemas que en ella y alrededor de ella se articulan.

El primero de tales complejos es la naturaleza y comportamiento de la oferta alimentaria, que implica el análisis de la disponibilidad, propiedad, acceso y experimentación con los recursos agroalimentarios (desde los productos que satisfacen las necesidades básicas hasta el material genético), la estructura y evolución geográficas de la producción e intercambio de productos agrícolas y de la industria alimenticia de transformación. El segundo complejo obliga analizar los problemas de la estructura y evolución de la demanda global, principalmente centrada en la relación entre trayectorias económico-sociales, las características de la distribución del ingreso, la disponibilidad y acceso a los recursos necesarios y las relaciones económicas en que se basa la creación de la riqueza social. Esto se traduce, a su vez, en el análisis en los logros o falencias en los patrones de crecimiento y desarrollo, en cambios relativos a la distribución socio-espacial del trabajo y la riqueza social en el mundo, la evolución y naturaleza del ingreso, la capacidad de acceso (compra e intercambio), de los patrones alimentarios de la población y sus consecuencias en el estado de salud y nutrición general.
No obstante, la oferta y la demanda alimentarias no pueden concebirse como procesos independientes o autónomos. Por el contrario, una y otra están determinadas por la dinámica de la organización productiva, económica, política y tecnológica del mundo actual. Justamente esa fundamental relación lo obliga hoy a que la cuestión alimentaria se aborde a la luz de las recientes transformaciones en el patrón y la espacialidad de la acumulación mundial, conocido en su acepción más aceptada como la globalización.

En un contexto tal, la cuestión alimentaria actual implica que demanda y oferta deban necesariamente referirse a un tercer complejo de problemas que surgen como resultado del proceso de globalización capitalista, a las transformaciones tecnológicas, geográficas y organizacionales de la producción, el comercio y la inversión, a las tendencias tecnológicas y su ligazón con la producción y a los cambios relacionados con estos factores en los patrones de división internacional del trabajo y del consumo.

Este artículo pretende relacionar varios de tales aspectos en el contexto de la situación actual del mundo. En un examen de las tendencias mundiales y con referencia a las condiciones de América Latina y el Caribe, el artículo caracteriza el momento actual como un complejo de continuidad y ruptura de las tendencias de largo plazo enraizadas en la naturaleza y cambios (reestructuración) del modo de producción capitalista. Así, la profundización de la crisis de acumulación, la generalización de la pobreza y del 
desempleo, la ampliación del abismo en la distribución de la riqueza tanto entre grupos sociales en los países como entre países y territorios y, principalmente, el carácter de la contradicción que emerge cuando un pequeño grupo de países subyuga a la mayoría de naciones en el mundo, son considerados como elementos que explican la creciente inseguridad alimentaria. Al tratar las contradicciones que subyacen en la relación produccióningreso-consumo de alimentos, tanto entre países y regiones como entre las áreas centrales metropolitanas y las periferias urbanas y entre estas y las áreas rurales, el artículo elabora unas determinaciones para comprender la situación alimentaria de comienzos del siglo XXI.

En la dirección de ubicar los asuntos de la seguridad alimentaria, la economía política, la biodiversidad, el desarrollo tecnológico y la política mundiales en relación con los cambios recientes, explícitamente el proceso de la globalización, el artículo propone ver la cuestión como una geo-economía mundial del hambre.

La creciente y más sistemática subordinación de las economías nacionales al proceso de globalización, expresada en la primacía cada vez mayor de los sistemas productivos de alta tecnología y gran capital, ha implicado el surgimiento de nuevas contradicciones para el desarro11 o y reproducción del proceso de acumulación. Entre las muchas, la concentración de capital, necesaria para emprender estrategias globales, implica también una extraordinaria centralización del capital en las naciones ricas y la mayor subordinación de economías y capitales pequeños y medianos de las naciones atrasadas.

La cada vez más amplia expansión de las compañías transnacionales -el mejor ejemplo de centralización de capital a escala global- la descapitalización de las economías semicoloniales y la obligada redefinición de la configuración económico-política de los estados nacionales, han hecho que las decisiones -tanto de esas mismas corporaciones como de los gobiernos de las naciones de que provienen- tengan cada vez mayor alcance. Como se puede notar en caso del comercio mundial de alimentos, las compañías multinacionales subordinan a sus intereses y estrategias las políticas de desarrollo y los objetivos de satisfacción de necesidades básicas que, mal que bien, constituían la antigua estructura de los estados nacionales.

Con particularidades y diferencias en cuanto al alcance y ritmo de las transformaciones, los programas de ajuste, apertura y modernización dictados desde las agencias internacionales y emprendidos por la mayoría de las economías del mundo han implicado la dramática agudización de las contradicciones sobre las que descansa la inseguridad alimentaria global.

La evolución de la mayoría de las economías dependientes en los años recientes sugiere que los beneficios de la globalización y el progreso tecnológico y científico, que pudieran ser enormes de existir formas de organización económi- 
ca y social distintas a las que hoy tenemos, no parecen estar tocando ni nuestras fronteras ni a las mayorías de nuestros pueblos.

Los desarrollos recientes revelan que los efectos de la globalización han profundizado y ampliado la pobreza y los abismos en la desigualdad del ingreso desde la escala global y nacional a las regionales y locales en el todo mundo. Con ellas, la inseguridad alimentaria se ha profundizado y no parecen emerger ni tendencias ni alternativas viables para su solución, a pesar de que, como lo reconociera el Foro sobre la Alimentación en el Mundo, organizado por la FAO (Roma, 1996), con las condiciones técnicas que tiene el mundo hoy es posible producir alimentos suficientes para satisfacer las necesidades de todos los seres humanos.

La globalización actual -la tercera que el capitalismo ha engendrado y que comenzó con la conquista y el pillaje de América y resultado de una permanente dinámica de crisis-expansión-crisis en el patrón de acumulación-, contiene las contradicciones propias del modo de acumulación: el enorme progreso en las fuerzas productivas y la persistencia de un tipo de relaciones de producción que encadenan el progreso generalizado; la apropiación privada de una enorme producción cada vez más socializada; la anarquía en la producción, el desarrollo desigual de naciones y territorios; las desigualdades en la distribución de la riqueza social; la división del mundo en un puñado de países que acrecienta su riqueza a costa de los países y regiones pobres; y, la férrea acción de la ley del valor en todas las actividades humanas. Justo las contradicciones que, por más de cuatro siglos, han estado en la base de la cuestión alimentaria.

Empero, la globalización actual contiene también elementos nuevos $\mathrm{y}$, en rigor, nuevos procesos y contradicciones que se articulan, en una relación de continuidad y ruptura, a la naturaleza de la acumulación de capital.

Entre estas nuevas contradicciones se destaca la que constata que, gracias a los enormes logros tecnológicos y productivos que hoy ha alcanzado la humanidad, el mundo actual está en capacidad de producir lo suficiente para satisfacer las necesidades alimentarias de todos. Sin embargo, la naturaleza del régimen de acumulación y la dinámica del capital, principalmente de las naciones ricas y de las clases dominantes en los países pobres, impiden que ello sea una realidad y que, en cambio, la producción alimentaria esté controlada por ese pequeño puñado de países y clases, y que sea deficitaria para la mayoría de los pueblos del mundo.

Una segunda evidencia que el papel y los cambios en la agricultura, operados por el proceso de reestructuración de las condiciones de acumulación de la globalización y apuntalado por la ideología neoliberal, han venido redefiniendo el carácter, función y estructura de los sectores productivos de las economías semicoloniales, las prioridades en cuanto a su desarrollo y sus relaciones con los 
países que controlan los circuitos globales de acumulación. Tal redefinición deja intacta la cuestión agraria, el monopolio de la tierra y el atraso de la producción campesina, los problemas centrales que impiden que, en la mayoría de países atrasados, se incremente la producción y la productividad agrícola.

La tercera se refiere a la redefinición de los sectores productivos operada por la globalización, y precisa que el control creciente de la producción por los capitales y corporaciones de las naciones ricas está en la base del aumento de la pobreza, la miseria, el desempleo y del abismo en la distribución doméstica e internacional de la riqueza. La continua reducción del ingreso de las mayorías, a su vez, constituye el principal factor que provoca la contracción de la demanda de alimentos básicos y el incremento de la inseguridad alimentaria a niveles más dramáticos de los que hoy tenemos.

El estancamiento de la agricultura en los países pobres, especialmente de la agricultura campesina, la reducción dramática del ingreso de las mayorías rurales y el recurso a las importaciones de alimentos, emergen como un haz de contradicciones que profundiza el abismo entre quienes pueden ingerir una dieta mínima y los que no pueden lograrlo, como ha ocurrido a lo largo de toda América Latina durante los años noventa. La disminución e inestabilidad del ingreso, el bajo crecimiento, la exigua capacidad de compra, los ajuste de la balanza comercial y un volátil comportamiento del mercado mundial de productos provenientes de las regiones atrasadas han hecho que, por otra parte, las voluminosas importaciones de alimentos sólo hayan alcanzado para cubrir las necesidades de las capas medias y altas, las únicas que pueden generar una demanda más o menos rentable para las corporaciones y sectores que están a la cabeza del negocio de alimentos. Esa realidad que hemos presenciado en los noventa, implica mayor diferenciación social y mayor exclusión de extensos sectores de la población a la oferta alimentaria.

La quinta contradicción refiere a las tendencias actuales del comercio mundial controlado por los países ricos a través de los acuerdos comerciales del GATT y la OMC que hoy concitan tanta resistencia en todos los foros mundiales. A pesar del creciente rechazo de las masas del mundo contra la globalización, la preeminencia de tales tendencias -referidas como el inicio de una supuesta gobernabilidad global que se extiende también a la política y al aparato jurídico-, sugieren pocos cambios en la actual división internacional del trabajo y en las condiciones de inequidad en la distribución de la riqueza mundial. Si el comercio mundial continúa siendo dominado por las corporaciones transnacionales, es difícil pensar que sus intereses se concilien con los intereses de los millones de hambrientos por todo el mundo. Estas nuevas tendencias llaman la atención al papel que juegan los subsidios en los países desarrollados y de mayor productividad y la posibilidad de que, si se levantan, esos países reduzcan la producción y, vía el incremento de precios y mayores 
dificultades para la importación, más y más personas en el mundo se vean privadas de alimentos. En la misma perspectiva, esta contradicción plantea incertidumbres respecto del papel que jugarán países como China y Europa del Este cuando vuelquen gran parte de sus excedentes al mercado internacional y entren a competir con los países hoy dominantes en los mercados de las naciones atrasadas y cómo su importación en las naciones pobres se convertirá en otro obstáculo para el fortalecimiento de un sector agrícola autónomo y la adopción de estrategias autocentradas de seguridad alimentaria.

El sexto aspecto encarna, en realidad, un complejo haz de contradicciones que examina y relaciona las tendencias actuales en la producción y comercio mundial de alimentos a la luz de los avances tecnológicos y científicos, el rápido desarrollo de la ciencia y la acción global de capitales y firmas. Un conjunto de nuevas y más complejas contradicciones han empezado a emerger en la configuración actual de la economía mundial y las cuales constituyen un obstáculo mayúsculo en la meta de garantizar la seguridad alimentaria. Nos referimos aquí a las formas de apropiación, uso y acceso de los recursos genéticos y de la biodiversidad que están en la base de la alimentación mundial. Ellas mismas sometidas, como la producción básica de alimentos y demás mercancías, a las leyes de la acumulación de capital, a la ley del valor y, por tanto, también a la aplicación de los paradigmas neoliberales de las ventajas comparativas, la especialización productiva y la competitividad.

Para examinar el complejo interplay de este conjunto de contradicciones en el mundo actual de la globalización, el presente artículo se desarrolla en tres partes:

La primera será, de una manera que trate de captar en su compleja interrelación, las cinco primeras contradicciones y procesos enunciados. Haciendo una referencia explícita a las condiciones de América Latina y el Caribe, pues, en la magnitud y dramatismo con que se expresan los problemas aludidos en la región, el artículo aspira a persuadir a los lectores de que es decisivo comprometernos con su superación. La segunda parte examina las implicaciones del último haz de contradicciones que tocan directamente con los problemas de la pérdida y apropiación de la biodiversidad, la biopiratería y las tendencias del derecho durante la globalización. Una tercera, presenta una breve y apretada síntesis de los problemas que caracterizan hoy la cuestión alimentaria.

Reflexionando desde la perspectiva de la economía política, el ensayo intenta proveer a los lectores la mejor y más confiable información sobre los problemas, procesos, asuntos, relaciones e implicaciones que estas contradicciones abarcan. No está en la definición del artículo proveer soluciones a las contradicciones aludidas, sino principalmente presentar un conjunto articulado de proposiciones y análisis para contribuir a

12 Jaime Bonilla-Godoy 
enriquecer, si es posible, el debate sobre los problemas de la seguridad alimentaria en el mundo de hoy.

Antes de abordar los temas aludidos, el autor precisa avanzar una conclusión que ha venido siendo el resultado de sus investigaciones sobre el asunto:

El artículo elabora, de principio a fin, los fundamentos que permiten reconocer que, pese a la pertinencia de las metas de tantas y tantas conferencias, foros, informes, investigaciones y estudios, y a los denodados esfuerzos de los especialistas en la materia, el problema de la desnutrición, la inseguridad alimentaria, la inequidad en el acceso y disfrute de la riqueza y la pobreza generalizada, permanecerán mientras no se resuelvan las contradicciones que engendran la acumulación capitalista y la división del mundo entre un puñado de países imperialistas y una masa de países oprimidos. Las actuales estrategias de expansión global del capital financiero y corporativo constituyen, ya sea para resolver los problemas de la seguridad alimentaria o del progreso económico, social y cultural de todas las naciones, antítesis del desarrollo equilibrado y autónomo de los pueblos del mundo.

\subsection{Oferta y demanda alimentaria mundial: un diagnóstico global}

El concepto de seguridad alimentaria supone garantizar el acceso regular a los alimentos en cantidad y calidad necesaria al conjunto de la población (tomando en cuenta incluso las diferencias individuales, intrafamiliares, y culturales). Si bien se enfrentó tradicionalmente como un problema de oferta de alimentos, alude fundamentalmente al problema de la demanda, dado los cambios en la capacidad adquisitiva de gran parte de la población marginada de los procesos de desarrollo.

Hace ya 55 años que, justo después de su creación, la Organización de las Naciones Unidas para la Agricultura y la Alimentación (FAO) dio a conocer el primer informe alimentario mundial (World Food Survey) referente a 70 países y más del $90 \%$ de la población mundial. Sin incluir a África tropical y un número de países asiáticos, ese informe concluía que la mitad de la población mundial estaba subalimentada (Sasson, 1993) y que esa situación alimentaria requería atención y compromiso multilateral inmediato. En función de ello, el recién creado organismo delineó distintos instrumentos y propósitos para identificar los problemas y ofrecer alternativas de tratamiento.

Entre los primeros, la FAO se percató de la necesidad de recopilar y sistematizar información sobre la magnitud del hambre y sobre las disponibilidades alimentarias en los países y sobre la situación alimentaria y nutricional de las poblaciones. Para atender de forma sistemática estas materias, estableció un modelo general para la elaboración, en cada país, de las Hojas de Balance de Alimentos (HBA).

Entre los segundos, la FAO se planteaba en el corto plazo la búsqueda de mecanismos para superar la crisis de la oferta alimentaria de la posguerra. A mediano 
y largo plazo, buscaba promover el diseño de políticas y programas para favorecer el desarrollo agrícola y ampliar la oferta alimentaria; enfrentar los problemas de déficit alimentario sobre todo en los países de bajos ingresos y favorecer la consolidación de la seguridad alimentaria a nivel mundial.

Para 1971, en su reunión de expertos con el fin de revisar las recomendaciones sobre las cantidades de energía y proteínas para cubrir las necesidades cotidianas, la FAO encontraba que los problemas de la alimentación mundial se habían multiplicado.

Paralelamente a las proposiciones de la FAO, entre finales de los años cuarenta y principios de los sesenta, aparecieron diversos trabajos teóricos y empíricos en diversas áreas del conocimiento que tocaban los problemas de la agricultura y la alimentación. En 1949, por ejemplo, J. De Castro publicaba un estudio denominado Geografía del Hambre que examinaba el problema de la indigencia alimentaria en los países del "tercer mundo". M. Sorre presentaba en 1952 su Geografía de la Alimentación, y un año más $\mathrm{M}$. Cépède y $\mathrm{M}$. Lengelle publican la Economía Alimentaria del Mundo. Con estos estudios, con los informes regulares de la FAO y otros estudios pioneros, el mundo ha constatado que la crisis alimentaria hundía sus raíces, primaria- mente, en las deficiencias de la oferta de alimentos sobre todo en los países deficitarios. $^{1}$

En 1974, cuando se llevó a cabo la primera Conferencia Mundial sobre la Alimentación, los Gobiernos del mundo proclamaban que "...todos los hombres, mujeres y niños tienen derecho inalienable a no padecer de hambre y desnutrición a fin de desarrollarse plenamente y conservar sus facultades físicas y mentales". Con esta declaración, asumían el compromiso de erradicar esos flagelos en menos de un decenio.

Con los impresionantes aumentos en la producción y productividad de alimentos y excedentes exportables de los países desarrollados durante los ochenta, y la situación cada vez más frágil en los países en desarrollo -asociados con la débil situación financiera, los efectos de la deuda externa sobre las economías, la agudización de la crisis económica de numerosos países y el deterioro de la capacidad económica efectiva de acceso a los alimentos del cada vez mayor número de personas en todos los países de bajos y medianos ingresos-, la discusión sobre el tema alimentario tornó paulatinamente al de la naturaleza de la demanda, principalmente a los problemas de accesibilidad desigual de pueblos y naciones a alimentos suficientes. ${ }^{2}$ A su turno, esta pobre accesibilidad era explicada como

1 Schejtman, A., (1994): Economía política de los sistemas alimentarios en América Latina. Santiago de Chile: Oficina Regional de la FAO para América Latina y el Caribe.

2 Schneider, H., (1984): La satisfaction des besoins alimentaires dans un monde en évolution. Paris: OCDE, Etudes de Centre de Développement. I.

14 Jaime Bonilla-Godoy 
el deterioro de la capacidad de compra alimentaria y las perversidades existentes en la repartición de la oferta alimentaria que reflejaban la desigual distribución de la riqueza en el mundo. ${ }^{3}$

En 1992, los 159 gobiernos reunidos en la Conferencia Internacional sobre Nutrición reiteraron su compromiso de "lograr que la liberación del hambre llegue a ser una realidad" y en "asegurar un bienestar nutricional duradero a todos". La lucha contra el hambre, el logro de una situación de seguridad alimentaria a largo plazo y la equidad en los resultados eran las metas. La Cumbre Mundial de la Alimentación de la FAO de octubre de 1997 fue la repetición de promesas y de debates ya ampliamente conocidos. Fue inaugurada con el lema de "Alimentos para todos", al reconocer que pese a las metas establecidas a nivel internacional, el mundo dista de cumplir los requisitos en términos de seguridad alimentaria y de lucha contra el hambre. Sin embargo, tanto los informes continuados como las conferencias y foros convocados por la FAO, y diversos estudios han constituido referencias pioneras en el desarrollo de líneas de trabajo en el ámbito de los estudios acerca de la producción agrícola y la situación alimentaria, ya que colocaron sobre el tapete uno de los mayores problemas enfrentados por el mundo: el problema de la alimentación en términos de disponibilidades y diferencias entre países y sus efectos sobre la seguridad alimentaria.

Hasta finales de los ochenta, la situación alimentaria mundial había mostrado una tendencia sostenida de treinta años al mejoramiento. El cuadro No. 1 muestra que, a pesar de los permanentes problemas de la oferta, el número de personas que sufrían de desnutrición crónica había disminuido $17 \%$ entre 1969 y 1990 , mientras la disponibilidad alimentaria (el consumo diario de calorías por habitante) había aumentado en $30 \%$ en promedio en los conocidos como países en vía de desarrollo. ${ }^{4}$

3 Advierte Sasson que: "...en realidad, los excedentes de los países industrializados contrastan claramente con la escasez de alimentos de numerosos países en desarrollo... Mientras en algunos países se acumulan centenares de millones de toneladas de excedentes alimentarios, la Reserva Alimentaria Internacional de Crisis, administrada por la FAO, sólo dispone de algunos cientos de miles de toneladas de cereales para afrontar situaciones de urgencia", Véase: SASSON, A., (1993): La alimentación del hombre del mañana. Barcelona: La Reverte.

4 Véase: FAO, 1993. 


\section{Cuadro No. 1}

\section{ESTIMATIVOS DE LAPOBLACION CON DESNUTRICION CRONICA EN 93 PAISES EN DESARROLLO ESTUDIADOS, 1969-1990}

\begin{tabular}{|l|c|c|c|c|c|}
\hline Región & Año & $\begin{array}{c}\text { Disponibilidad } \\
\text { alimentaria } \\
\text { por habitante } \\
\text { (calorías/día) }\end{array}$ & $\begin{array}{c}\text { Población } \\
\text { total de } \\
\text { habitantes } \\
\text { (millones) }\end{array}$ & $\begin{array}{c}\text { Población con } \\
\text { desnutrición } \\
\text { crónica } \\
\text { (\% del total) }\end{array}$ & $\begin{array}{c}\text { Población con } \\
\text { desnutrición } \\
\text { crónica } \\
\text { (millones) }\end{array}$ \\
\hline \multirow{2}{*}{ África } & $1969 / 71$ & 2.140 & 268 & 35 & 94 \\
Subsahariana & $1979 / 81$ & 2.120 & 358 & 36 & 129 \\
\hline Cercano Oriente & $1988 / 90$ & 2.100 & 473 & 37 & 175 \\
y Norte de África & $1969 / 71$ & 2.380 & 178 & 24 & 42 \\
& $1979 / 81$ & 2.830 & 233 & 10 & 23 \\
\hline Asia Oriental & $1988 / 90$ & 3.010 & 297 & 8 & 24 \\
& $1969 / 71$ & 2.020 & 1.120 & 44 & 497 \\
& $1979 / 81$ & 2.340 & 1.358 & 26 & 359 \\
\hline Sur de Asia & $1988 / 90$ & 2.600 & 1.558 & 16 & 252 \\
\hline América Latina & $1969 / 71$ & 2.040 & 738 & 34 & 254 \\
y el Caribe & $1979 / 81$ & 2.100 & 926 & 31 & 285 \\
& $1988 / 90$ & 2.220 & 1.144 & 24 & 271 \\
\hline TOTAL & $1969 / 71$ & 2.500 & 281 & 19 & 54 \\
& $1979 / 81$ & 2.690 & 357 & 13 & 47 \\
& $1988 / 90$ & 2.690 & 433 & 13 & 59 \\
\hline
\end{tabular}

Fuente: FAO, 1993.

Los importantes progresos en la productividad agrícola mundial alcanzados durante la segunda parte del siglo hacían posible que la oferta global de alimentos fuera suficiente para satisfacer las necesidades básicas de todo el mundo. ${ }^{5}$ Sin embargo, ad portas del nuevo siglo esa meta no ha podido hacerse realidad. En lo que sigue se examinan las contradicciones que explican esta disparidad manifiesta y se proponen algunos elementos de análisis para entender $-\mathrm{y}$ eventualmente atacar- el problema de la inseguridad alimentaria.

5 Entre 1961 y 1993, la producción de cereales pasó de 877 a 1894 millones de toneladas; y sólo en los países en desarrollo se triplicó pasando de 396 a 1089 millones de toneladas. Entre 1979-81 y 199193, la producción mundial de alimentos creció 29 por ciento, con aumentos de 49 por ciento en los países en desarrollo (689 por ciento de incremento solamente en China). Incluso en África, el aumento alcanzó 39 por ciento. Al respecto, véase: FAO, 1994. Según el Banco Mundial, el rol de los aumentos en productividad era, entre 1960 y 1990 , la fuente del 92 por ciento del aumento en la producción de cereales, mientras que la expansión en el área cultivada era la fuente del restante 8 por ciento, aunque tal expansión empezó a declinar preocupantemente en los países pobres desde la segunda mitad de los ochenta cuando los estímulos fiscales y financieros fueron eliminados en la mayoría de estos países. Véase: World Bank, 1992. Para un análisis más detallado de la evolución de la producción y productividad agrícola mundial, véase Rosegrant y Svendsen 1993.

16 Jaime Bonilla-Godoy 
1.2 La cuestión alimentaria mundial: su naturaleza y sus contradicciones

Un primer factor que hace que la disparidad entre la demanda y la oferta alimentarias se acreciente y que más y más personas no puedan acceder a una mínima dieta, es el ritmo de crecimiento poblacional, particularmente agudo después de los cincuenta. Al iniciar los noventa, ese era un aspecto importante del déficit que impedía que la meta de alimentar a todos fuera una realidad. De hecho, la producción alimentaria difícilmente podía equipararse con el incremento de la población mundial. Mientras el crecimiento de la población alcanzaba 2.1 por ciento anual, la producción per cápita de alimentos no alcanzaba el 5 por ciento entre 1979-81 y 1991-93, aunque en los países en desarrollo el aumento alcanzaba 16 por ciento. Sin embargo, examinando en detalle las tendencias de la matriz producción-consumo global de alimentos, rápidamente se evidencia que esta no es, aún con lo importante, la contradicción principal de la cuestión alimentaria.

\subsubsection{La inequidad de ingresos, la pobreza creciente y la contracción de la demanda}

El gran problema que impide que todos los seres humanos aseguren su alimentación radica en la distribución desigual de la riqueza y de los logros en productividad entre países y regiones.
Según estimaciones de la FAO, para finales de los ochenta, 800 millones de personas en todo el mundo, $20 \%$ de toda la población, no podía acceder a una dieta mínima. La inmensa mayoría de ella vivía en el África Subsaharaiana, el Cercano Oriente, el Norte de África, el Sur de Asia, América Latina, el Caribe y Asia Oriental. Y entre todos ellos, 180 millones de niños menores de cinco años pesaban menos que el promedio de su edad, 600 millones de personas mostraban déficit de grasas, minerales y vitaminas esenciales y sufrían las enfermedades propias de la pobreza. ${ }^{6}$

Los cambios acaecidos en la mayoría de los países de esas grandes regiones durante los noventa, como resultado de los procesos de ajuste y estabilización que siguieron a la crisis de la deuda, las políticas de liberación y reestructuración y la crisis de 1997 provocada por la voracidad de los flujos financieros - que afectó a inmensos segmentos de la población que vivía en situación de fragilidad crítica en los países asiáticos, Rusia, Brasil y otros países latinoamericanos- rompieron rápidamente la tendencia positiva que se apreciaba hasta comienzos de los noventa y a imponer una de empeoramiento progresivo.

Entre tanto, los países de Europa Occidental, Norteamérica y Japón concentran no sólo una inmensa cantidad de excedentes alimentarios, sino que

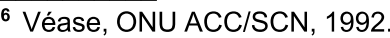


concentraban también los más altos niveles de productividad agrícola, la mayor diversificación del procesamiento industrial y semi-industrial de alimentos $\mathrm{y}$, por poseer la capacidad económica y tecnológica requerida, daban saltos decisivos en el mejoramiento de su producción con la introducción de los organismos genéticamente modificados para las principales cosechas.

Lo que estas trayectorias tan dispares sugieren es que la inseguridad alimentaria mundial es, principalmente, expresión y consecuencia de la división del mundo entre un puñado de países ricos y una gran masa de países empobrecidos y de la relación de dominación de unos sobre otros por obra y gracia de la acumulación de capital. En palabras breves, esta inaceptable división del mundo y sus incidencias en la cuestión alimentaria son el resultado de la existencia del imperialismo.
Aguzada por su expresión más reciente, la globalización, la omnipotencia del capital financiero y la organización de la producción que las corporaciones transnacionales adelantan en todo el mundo, el imperialismo explica los inmensos contrastes y desigualdades en la distribución de la riqueza entre países y naciones que están en la base del aumento dramático de la pobreza y la inseguridad alimentaria en el mundo.

Si examinamos sucintamente las incidencias de la pobreza en la era de la globalización, rápidamente encontraremos que el viejo patrón de inequidad -un puñado de países que lo tienen y producen todo y la mayoría que no tienen nada-se ha venido profundizando y las distancias entre unos y otros ampliándose peligrosamente. 
Cuadro No. 2a

La Pobreza en los Países en Desarrollo y las Economías en Transición

1987-1998

Población que vive con menos de US \$1 dólar por día

\begin{tabular}{|c|c|c|c|c|c|c|c|c|c|c|c|}
\hline \multirow[t]{2}{*}{ Región } & \multirow{2}{*}{$\begin{array}{c}\text { Población } \\
\text { cubierta } \\
(\%)\end{array}$} & \multicolumn{5}{|c|}{$\begin{array}{l}\text { Población total que vive con menos de US\$1 } \\
\text { Dólar diario (millones) }\end{array}$} & \multicolumn{5}{|c|}{$\begin{array}{l}\text { Porcentaje del total } \\
(\%)\end{array}$} \\
\hline & & 1987 & 1990 & 1993 & 1996 & $1998 \mathrm{e}$ & 1987 & 1990 & 1993 & 1996 & $1998 \mathrm{e}$ \\
\hline Asia Oriental y Pacífico & 90.8 & 417.5 & 452.4 & 431.9 & 265.1 & 278.3 & 26.6 & 27.6 & 25.2 & 14.9 & 15.3 \\
\hline Excluyendo China & 71.1 & 114.1 & 92.0 & 83.5 & 55.1 & 65.1 & 23.9 & 18.5 & 15.9 & 10.0 & 11.3 \\
\hline América Latina y el Caribe & 88.0 & 63.7 & 73.8 & 70.8 & 76.0 & 78.2 & 15.3 & 16.8 & 15.3 & 15.6 & 15.6 \\
\hline Oriente Medio y Norte de África & 52.5 & 9.3 & 5.7 & 5.0 & 5.0 & 5.5 & 4.3 & 2.4 & 1.9 & 1.8 & 1.9 \\
\hline Asia del Sur & 97.9 & 474.4 & 495.1 & 505.1 & 531.7 & 522.0 & 44.9 & 44.0 & 42.4 & 42.3 & 40.0 \\
\hline África Subsahariana & 72.9 & 217.2 & 242.3 & 273.3 & 289.0 & 290.9 & 46.6 & 47.7 & 49.7 & 48.5 & 46.3 \\
\hline
\end{tabular}

e: Estimado.

Fuente: Chen y Ravallion y Banco Mundial, 1999. 
$\mathrm{Si}$ supusiéramos que un dólar norteamericano es suficiente para que una persona pueda comprar sus requerimientos alimenticios diarios, un exabrupto evidente, el cuadro No. 2a muestra que no son sólo 800 sino 1.200 millones las personas ( 24 por ciento de la población mundial) que, con ingresos inferiores a 1 dólar por día, no recibe el nuevo milenio con el mismo boato que mostraron las cadenas globales de televisión, sino en condiciones de extrema miseria, hambre y desesperanza.
Un cuadro más veraz debería incluir a, por lo menos, 2.800 millones de personas (56 por ciento de la población mundial) que, como resultado de las continuadas crisis nacionales, el creciente desempleo, los programas de ajuste en casi todas las naciones y la ampliación de la pobreza, vieron reducido terriblemente su nivel de ingresos y, después de pertenecer a las capas de ingresos medios, cayeron estrepitosamente bajo la línea de la pobreza $^{7}$. El cuadro No. 2a incluye a las personas que ganan menos de dos dólares diarios:

7 La crisis financiera que se inició en varios países asiáticos y que, con el conocido "efecto dominó" se difundió rápidamente sobre Rusia, Brasil, México y otras naciones, puso de relieve la manera en que la globalización, y especialmente la dinámica del capital financiero pone a los países en desarrollo en una situación de vulnerabilidad frente a las conmociones externas. Aunque las repercusiones sociales negativas de la crisis de Asia oriental y las consiguientes crisis de Rusia y Brasil fueron muy heterogéneas y aún no cuantificadas realmente, su magnitud fue monumental. El aumento de la pobreza ha sido significativo para los sectores más vulnerables. Además, la crisis generó onerosos y enormes traslados de gente y una abrupta disminución en el nivel de vida de la clase media. La magnitud de esos efectos depende del nivel de ingresos del país y de las consecuencias de la crisis en los distintos sectores económicos. Según insisten los informes periódicos del Banco Mundial, en Asia oriental los efectos en la distribución de los ingresos fueron leves y muy diferenciados, pero en América Latina las desigualdades en los ingresos aumentaron considerablemente durante la crisis. La pobreza urbana aumentó en todos los países, especialmente en Corea donde disminuyó el empleo total y el desempleo manifiesto aumentó más que en otros países de la región. La crisis puso de manifiesto también la flexibilidad de los mercados laborales de los países en desarrollo. Esos mercados ayudan a absorber los efectos de las conmociones mediante una reducción de los salarios y una movilidad de la mano de obra dentro de las zonas urbanas y rurales, así como entre ellas. La caída de los salarios reales en el sector estructurado urbano afectó en su mayor parte a los grupos de altos ingresos. En Tailandia, por ejemplo, los efectos se sintieron mayormente en las zonas rurales debido a la gran cantidad de trabajadores que emigraron de las zonas urbanas y los aumentos relativamente pequeños en los precios de los productos agrícolas. La gravedad de la crisis en Indonesia se vio reflejada en el hecho de que la mayoría de los hogares aumentó la proporción del consumo en relación con sus ingresos, modificó su tenencia de activos y aumentó la proporción de alimentos básicos en su canasta familiar. Según el informe Global Economic Prospects and the Developing Countries 2000, publicado anualmente por el Banco Mundial, la recuperación de la crisis financiera es "frágil e irregular" algunas regiones se están recuperando mucho más rápidamente que otras.

20 Jaime Bonilla-Godoy 


\section{Cuadro No. 2b}

La Pobreza en los Países en Desarrollo y las Economías en Transición 1987-1998 Población que vive con menos de US\$2 dólares por día

\begin{tabular}{|c|c|c|c|c|c|c|c|c|c|c|c|}
\hline \multirow[t]{2}{*}{ Región } & \multirow[t]{2}{*}{$\begin{array}{r}\text { Población } \\
\text { cubierta }\end{array}$} & \multicolumn{5}{|c|}{$\begin{array}{c}\text { Población total que vive con menos de US\$2 } \\
\text { dólares diario (millones) }\end{array}$} & \multicolumn{5}{|c|}{ Porcentaje del total (\%) } \\
\hline & & 1987 & 1990 & 1993 & 1996 & $1998 \mathrm{e}$ & 1987 & 1990 & 1993 & 1996 & $1998 \mathrm{e}$ \\
\hline Asia Oriental y Pacífico & 90.8 & 1052.3 & 1084.4 & 1035.8 & 863.9 & 892.2 & 67.0 & 66.1 & 60.5 & 48.6 & 49.1 \\
\hline Excluyendo China & 71.1 & 2999.9 & 294.9 & 271.6 & 236.3 & 260.1 & 62.9 & 57.3 & 51.6 & 42.8 & 45.0 \\
\hline América Latina y el Caribe & 88.0 & 147.6 & 167.2 & 162.2 & 179.8 & 182.9 & 35.5 & 38.1 & 35.1 & 37.0 & 36.4 \\
\hline Oriente Medio y Norte de África & 52.5 & 65.1 & 58.7 & 61.7 & 60.6 & 62.4 & 30.0 & 24.8 & 24.1 & 22.2 & 21.9 \\
\hline Asia del Sur & 97.9 & 911.0 & 976.0 & 1017.8 & 1069.5 & 1095.9 & 86.3 & 86.8 & 85.4 & 85.0 & 84.0 \\
\hline África Subsahariana & 72.9 & 356.6 & 388.2 & 427.8 & 457.7 & 474.8 & 76.5 & 76.4 & 77.8 & 76.9 & 75.6 \\
\hline
\end{tabular}

e: Estimado

Fuente: Chen y Ravallion y Banco Mundial, 1999. 
La cuantificación de la inseguridad alimentaria y la pobreza absoluta durante los noventa ha evidenciado dos tendencias también contradictorias: mientras que, por un lado, la proporción relativa de pobres en los países atrasados y las llamadas economías en transición tendía a disminuir (una aparente disminución de 28 a 24 por ciento de personas que vivían con menos de un dólar diario registrada entre 1987 y 1998); por el otro, se observa que, en términos absolutos, el número de personas en la indigencia creció. Así, sin incluir a China, el número de personas que vive en condiciones de miseria pasó de 880 a 980 millones. Entre tanto y sin cuantificar los impactos de la crisis asiática de 1997-98, el número de personas que viven con un máximo de dos dólares diarios creció 250 millones en el curso de sólo 10 años, alcanzando los 2.800 millones. Si incluimos las estimaciones preliminares de los impactos de esa crisis tanto en Asia como en Rusia y América Latina y de la recesión de diversas economías latinoamericanas entre 1997 y 1999 , el número total de pobres viviendo con un mínimo de 2 dólares al día se acercaba dramáticamente, en los albores del nuevo milenio, a los $3000 \mathrm{mil}$ millones de personas. ${ }^{8}$ Esta es la evolución de la pobreza y de la reducción de la demanda por alimentos justo en el periodo en que el mundo habría experimentado los beneficios de la globalización y en el que las economías y estados nacionales habrían alcanzado, por obra de la reestructuración neoliberal, más libertades, mayor progreso y cultura que en todas las épocas anteriores. Los Mapa 1 y 2 muestran claramente esta terrible disparidad.

La contradicción relativa a la desigualdad en la distribución de la riqueza y de los beneficios del progreso implica también elementos de incertidumbre para el futuro cercano. De hecho, la preocupación por la terrible contracción de la demanda no estriba solamente en cómo satisfaremos en años venideros las necesidades alimenticias de esos 3.000 millones de personas que hoy viven en la miseria absoluta o en la pobreza y de las capas medias pauperizadas por efectos de la crisis reciente. La preocupación es también por cómo asegurar acceso a alimentos básicos a los 2.300 millones de personas que se adicionarán a la población mundial en los próximos 25

\footnotetext{
8 Las estadísticas y estimaciones disponibles revelan importantes diferencias regionales. En Asia Oriental y el Pacífico, la disminución de la pobreza ha sido dramática tanto en términos relativos como absolutos. Incluyendo a China, el número de personas que no alcanzan a tener un dólar por día para vivir pasó de 418 millones ( 27 por ciento) a 278 millones (15 por ciento) entre 1987 y 1998 . Excluyendo a China, el número de indigentes habría caído de 114 millones (24 por ciento) a 65 millones (11 por ciento) durante el mismo periodo. No obstante, en las demás regiones, la cantidad de personas viviendo en la pobreza y la indigencia se incrementó. En África Subsahariana, el número de personas que viven con un dólar diario pasó de 220 a 290 millones en los mismos diez años. En el sur de Asia (India, Bangladesh, Sri Lanka, Pakistán), el número de personas en la miseria aumentó 48 millones, y en las llamadas economías en transición de Europa del Este y Asia Central aumentó 27 millones. En América Latina y el Caribe, el incremento absoluto de personas en la miseria alcanzó los 14 millones.
}

22 Jaime Bonilla-Godoy 
años, si tenemos en cuenta que ésta crecía en cerca de 90 millones de personas al año según las proyecciones de las Naciones Unidas (UN, 1993). El asunto de la inseguridad alimentaria implica, pues, tanto preocupaciones y pesimismo en relación con la población actual que padece de hambre en el mundo, como también de la población que la sufrirá en los próximos años.

\subsubsection{El abismo tecnológico entre países y el control de la oferta alimentaria}

Al tiempo que, con ruidosa algarabía, brindis de champaña y fuegos pirotécnicos, una pequeñísima y muy refinada porción de la población mundial daba la bienvenida al nuevo milenio y celebraba con boato los beneficios de la globalización, los avances científicos, tecnológicos y productivos, el mercado libre y el "triunfo" de la democracia occidental, el mundo ha seguido constatando la creciente concentración de excedentes agrícolas en los países imperialistas, justo allí donde proliferan cuantiosos subsidios al sector agrícola y se concentra la inversión en investigación, tecnología y extraordinarias ganancias en productividad.

La contradicción entre la capacidad potencial de todos los países para producir los alimentos necesarios para la población mundial, por un lado, y la imposibilidad de que esto sea una realidad y que, al contrario, una inmensa cantidad de seres humanos reciban cada noche sin haber ingerido una dieta básica y no puedan demandar efectivamente los alimentos producidos, por el otro, descansa en la racionalidad que rige y organiza la sociedad en su conjunto.

En efecto, en la base de la pobreza, la desigual distribución de la riqueza entre naciones, regiones y sectores de la población y la dominación de los países ricos sobre el resto del mundo estriba la lógica de la acumulación de capital y el intercambio de mercancías: la búsqueda de la ganancia como criterio central de organización económico-social. De ello dependen las fuerzas y factores estructurales que, en el capitalismo, impiden que todos los seres humanos accedan a los alimentos básicos de una manera regular y a costos bajos.

Una de las expresiones más acuciantes que tal lógica asume es que, aún si el mundo puede disponer de suficientes alimentos, tal disponibilidad global no significa su acceso por parte quienes la necesitan. No es, pues, el criterio de la satisfacción de las necesidades sino la búsqueda de la ganancia la que orienta la oferta mundial de alimentos.

La lógica de la acumulación capitalista hace que las condiciones del mercado en los países del mundo se caractericen por la centralización de la producción, el comercio y la inversión mundiales en sólo algunas regiones y un número pequeño de países. Durante la última década, cuatro quintas partes de la producción manufacturera mundial seguían concentradas en Norteamérica, Europa Occidental y Japón; y $86 \%$ en 15 países, 
con Estados Unidos, Japón y Alemania monopolizando el 55\%. ${ }^{9}$

En el caso del comercio, la tendencia de concentración en las naciones más ricas se mantiene aunque algunas, recientemente industrializadas (NICs, por sus siglas en lengua inglesa) de Asia han venido incrementando su participación en las exportaciones y las importaciones hacia y desde las economías industrializadas: solamente en 1998, 75.6 por ciento de todas las exportaciones mundiales iban a los países que el Banco Mundial llama "economías de altos ingresos" que incluyen a Estados Unidos, la Unión Europea y Japón; mientras que esos mismos países concentraban 75.8 por ciento de las importaciones. Los países de ingresos medios y bajos, en conjunto, solo vendían a los primeros 17.6 por ciento de todas las exportaciones mundiales y participaban con 24.2 por ciento de las importaciones. Un cuadro más detallado de estas tendencias puede verse en el cuadro No. 3.

La tendencia refleja también que los países que producen más manufacturas, concentran también la exportación de servicios (financieros, comerciales y apoyo a los negocios las cuales alcanzaron $73 \%$ del total de sus exportaciones y $70 \%$ del total de sus importaciones en 1998).

\footnotetext{
9 Aunque por obra de la internacionalización de la producción durante los setentas y el proceso actual de globalización liderado por las corporaciones multinacionales y el capital financiero de los países imperialistas, una parte considerable de la producción manufacturera empezó a trasladarse a las llamadas "economías en desarrollo", sólo siete u ocho países recientemente industrializados podian caracterizarse como países en desarrollo. La gran mayoría de los países atrasados tiene sólo una pequeñísima base manufacturera. Véase: GLOBAL FORUM ON INDUSTRY, (1995). Perspectives for 2000 and Beyond.. Panel III Globalization and industrial partnerships. Globalization of manufacturing activity: Evidence and implications for industrialization in developing countries. Preparado por PETER NUNNENKAMP and ERICH GUNDLACH. UNITED NATIONS INDUSTRIAL DEVELOPMENT ORGANIZATION. New Delhi, Octubre. Véase también: World Bank, (2000): Global Economic Prospects and the Developing Countries 2000. URL: www.worldbank.org.
}

24 Jaime Bonilla-Godoy 
Cuadro No. 3

Origen y Destino de las Importaciones y Exportaciones Mundiales por grupos de países

\begin{tabular}{|c|c|c|c|c|c|c|}
\hline \multicolumn{7}{|c|}{$\begin{array}{l}\text { a. Dirección del Comercio (\% del Comercio Mundial, 1998) } \\
\text { Economías Importadoras de altos ingresos }\end{array}$} \\
\hline Fuente de las exportaciones & $\begin{array}{l}\text { Unión } \\
\text { Europea }\end{array}$ & Japón & $\begin{array}{l}\text { Estados } \\
\text { Unidos }\end{array}$ & $\begin{array}{c}\text { Total } \\
\text { Economías } \\
\text { Industria- } \\
\text { lizadas }\end{array}$ & $\begin{array}{c}\text { Otras } \\
\text { Economías } \\
\text { Ingresos } \\
\text { altos }\end{array}$ & $\begin{array}{c}\text { Total } \\
\text { Economías } \\
\text { Ingresos } \\
\text { altos }\end{array}$ \\
\hline Economías de Altos Ingresos & 32.0 & 2.8 & 11.0 & 53.4 & 5.2 & 58.5 \\
\hline Unión Europea & 24.7 & 0.6 & 3.2 & 32.0 & 1.4 & 33.4 \\
\hline Japón & 1.3 & & 2.2 & 3.9 & 1.3 & 5.1 \\
\hline Estados Unidos & 2.8 & 1.1 & & 7.1 & 1.1 & 8.1 \\
\hline Otras economías de altos ingresos & 1.4 & 0.7 & 1.9 & 4.3 & 1.1 & 5.4 \\
\hline Economías de Ingresos medios y bajos & 6.1 & 1.9 & 5.6 & 14.4 & 2.6 & 17.0 \\
\hline Asia Oriental \& Pacífico & 1.6 & 1.4 & 2.0 & 5.5 & 2.2 & 7.6 \\
\hline Europa \& Asia Central & 2.3 & 0.1 & 0.2 & 2.7 & 0.1 & 2.8 \\
\hline América Latina \& Caribe & 0.7 & 0.1 & 2.7 & 3.7 & 0.1 & 3.7 \\
\hline Medio Oriente \& Norte de África & 0.7 & 0.2 & 0.2 & 1.1 & 0.1 & 1.2 \\
\hline Sur de Asia & 0.3 & 0.0 & 0.2 & 0.6 & 0.1 & 0.7 \\
\hline África Sub-Sahariana & 0.5 & 0.1 & 0.2 & 0.8 & 0.1 & 0.9 \\
\hline Mundo & 38.0 & 4.7 & 16.6 & 67.8 & 7.8 & 75.6 \\
\hline
\end{tabular}

\begin{tabular}{|c|c|c|c|c|c|c|c|c|}
\hline \multicolumn{9}{|c|}{$\begin{array}{l}\text { b. Dirección del Comercio (\% del Comercio Mundial, 1998) } \\
\text { Economías importadoras de ingresos medios y bajos }\end{array}$} \\
\hline $\begin{array}{l}\text { Fuente de las } \\
\text { Exportaciones }\end{array}$ & $\begin{array}{c}\text { Asia } \\
\text { Oriental } \\
\text { y el } \\
\text { Pacífico }\end{array}$ & $\begin{array}{c}\text { Europa } \\
\text { del Este } \\
\text { \& Asia } \\
\text { Central }\end{array}$ & $\begin{array}{l}\text { América } \\
\text { Latina \& } \\
\text { el Caribe }\end{array}$ & $\begin{array}{c}\text { Medio } \\
\text { Oriente } \\
\text { \& Norte } \\
\text { Africa }\end{array}$ & $\begin{array}{c}\text { Sur } \\
\text { de } \\
\text { Asia }\end{array}$ & $\begin{array}{c}\text { Africa } \\
\text { Subsaha- } \\
\text { riana }\end{array}$ & $\begin{array}{c}\text { Econom. } \\
\text { ingreso } \\
\text { medio } \\
\text { y bajo }\end{array}$ & $\begin{array}{c}\text { Total } \\
\text { Mundo }\end{array}$ \\
\hline Economías de altos ingresos & 5.8 & 3.8 & 4.4 & 1.7 & 0.7 & 0.9 & 17.3 & 75.8 \\
\hline Unión Europea & 1.0 & 3.2 & 1.1 & 1.0 & 0.2 & 0.6 & 7.2 & 40.5 \\
\hline Japón & 1.3 & 0.1 & 0.4 & 0.2 & 0.1 & 0.1 & 2.0 & 7.1 \\
\hline Estados Unidos & 1.0 & 0.2 & 2.6 & 0.3 & 0.1 & 0.1 & 4.3 & 12.5 \\
\hline Otras economías de altos ingreso & 2.2 & 0.1 & 0.2 & 0.1 & 0.2 & 0.1 & 2.9 & 8.3 \\
\hline $\begin{array}{l}\text { Economías de ingresos } \\
\text { medios y bajos }\end{array}$ & 2.1 & 2.0 & 1.5 & 0.6 & 0.5 & 0.5 & 7.1 & 24.2 \\
\hline Asia Oriental \& Pacífico & 1.4 & 0.3 & 0.3 & 0.2 & 0.2 & 0.1 & 2.5 & 11.1 \\
\hline Europa \& Asia Central & 0.1 & 1.5 & 0.1 & 0.1 & 0.0 & 0.0 & 1.9 & 4.7 \\
\hline América Latina-Caribe & 0.1 & 0.1 & 1.1 & 0.1 & 0.0 & 0.0 & 1.4 & 5.1 \\
\hline Medio Oriente-Norte de África & 0.3 & 0.1 & 0.0 & 0.1 & 0.1 & 0.0 & 0.7 & 1.9 \\
\hline Sur de Asia & 0.1 & 0.0 & 0.0 & 0.0 & 0.1 & 0.0 & 0.2 & 1.0 \\
\hline África Subsahariana & 0.1 & 0.0 & 0.0 & 0.0 & 0.0 & 0.2 & 0.4 & 1.3 \\
\hline Mundo & 7.9 & 5.8 & 5.9 & 2.3 & 1.1 & 1.4 & 24.4 & 100.0 \\
\hline
\end{tabular}

Fuente: World Bank Group, 1999. 
Cálculos realizados alrededor de 1991 mostraban ya que, bajo semejante lógica, Estados Unidos, Francia, Canadá, Australia, Alemania y Tailandia concentraban $70.5 \%$ de las exportaciones mundiales de alimentos. La producción de carne fresca y congelada se concentraba en 1990 en los Países Bajos, Estados Unidos, Francia, Alemania, Australia, Dinamarca, Bélgica, Luxemburgo y Nueva Zelanda con $75.5 \%$, mientras que el $40.8 \%$ de la producción y exportación de frutas frescas y secas se concentraba en 1992 en Estados Unidos, España, Italia y Francia. En el rubro de las legumbres frescas, secas y congeladas, $54.8 \%$ de las exportaciones de 1991 se concentraron en los Países Bajos, Estados Unidos, Francia y España. ${ }^{10}$

Con la dimensión global de la nueva geoeconomía, los emporios financieros, manufactureros y comerciales de los países ricos han venido profundizando también el control de los mercados de alimentos primarios y procesados. $\mathrm{La}$ emergencia de una nueva división del trabajo agroalimentario, característico de este periodo, emerge como otra contradicción que adiciona nuevas características y profundiza la crisis alimentaria global. El aspecto complementario de semejante ordenamiento de cosas se registra con la creciente inundación y dependencia de las importaciones de alimentos en los países que, por muchos años, habían alcanzado su autonomía alimentaria y, hasta cierto punto, habían logrado producir excedentes para la exportación.

\subsubsection{Las directrices neoliberales $y$ las contradicciones del comercio mundial de alimentos}

Basados en el criterio de las "ventajas comparativas" y los extraordinarios logros tecnológicos y de productividad, los países ricos acrecentaron desde los ochenta su especialización en la producción de cereales, leche, carne y oleaginosas. Con el mismo criterio, los países oprimidos se convertían en importadores netos de aquellos bienes $y$, paradójicamente, en productores y exportadores de bienes agrícolas de consumo suntuoso o complementario (frutas exóticas, flores y hortalizas). Por supuesto, a pesar de que se esforzaban fieramente por alcanzar los mercados internacionales, no todos estos países habían logrado insertarse en esta nueva división internacional del trabajo agrícola y alimentario.

\footnotetext{
10 Véase al respecto, PANTOJA, E. (1987). "El traspatio productivo de los EEUU”, en Nueva Sociedad, Núm. 89, mayo-junio. Caracas; Rubio, B. (1995). "La vía agroexportadora-neoliberal en América Latina y el nuevo orden agrícola internacional", en Alejandro Encinas (Coord.), El campo mexicano en el umbral del siglo XXI. Espasa Calpe Hoy, México; y ESPINOSA CORTÉS, Luz María, (1997): La agricultura de alimentos y la política exterior de Estados Unidos. Departamento de Estudios Experimentales Rurales, Instituto Nacional de la Nutrición "Salvador Zubirán". México, D.F., México. Accédase a través de: URL:www.ergosum.ueamex.mx.
} 
En el cúlmen de tan inaceptable orden de cosas impuesto por la reestructuración neoliberal -que ha incluido el abandono de diversas políticas que en su momento fueron decisivas para el despegue de los circuitos de acumulación y la consolidación de una burguesía burocrática en varias naciones (tales como el modelo de industrialización sustitutiva, el despegue de la agricultura comercial y la autonomía alimentaria como dinamizadora de la acumulación y el mercado internos)-, el sector agrario de muchos países rápidamente se hundió en la crisis y los países se vieron forzados a suplir sus necesidades internas con masivos incremento de las importaciones de alimentos, particularmente de productos como los cereales que alcanzaron bajos precios alcanzados en el mercado internacional.

El intercambio de alimentos a bajos precios, que sería motivo de inmenso optimismo si el orden mundial estuviese basado en la satisfacción de las necesidades y no en la ley del valor, es contrariamente el origen de nuevas y más álgidas contradicciones tanto en el lado de la oferta como en el de la demanda alimentaria:

La mayor competitividad y la disminución de costos de producción de los alimentos en los países del norte ha producido la disminución real de sus precios reales bis a bis los precios de productores ineficientes en otras latitudes. Esto ha aumentado el índice de penetración de las importaciones de tales productos en todas las economías y, como resultado, numerosos productores domésticos en distintas naciones han quebrado, mientras que grandes contingentes de trabajadores del campo han quedado fuera de los circuitos laborales y de consumo, y no cuentan hoy con la capacidad adquisitiva mínima para acceder a productos baratos para su sustento y el de sus familias. ${ }^{11}$ En las áreas urbanas, los sectores de ingresos medios y bajos empobrecidos por las crisis sucesivas y por los programas de ajuste -principalmente los obreros, los campesinos emigrados y desplazados, los desempleados, los trabajadores informales y las clases medias- se ven impedidos de acceder a productos importados o domésticos producidos a menores costos. Esa es la verdad de lo que ha significado la "sangre, el sudor y las lágrimas de las masas" a que aludió un ministro de estado colombiano para anunciar aún nuevas y más dramáticas medidas de política fiscal.

Como corolario de este panorama de la globalización, que muchos celebran y califican como el fortalecimiento de la

11 Para el caso de Latinoamérica, véase, por ejemplo: Valdés, Alberto and Tom Wiens (1995): Rural Poverty In Latin America and The Caribbean. Annual Bank Conference on Development in Latin America and the Caribbean. Véase también: Pisani , Edgard, (1995): Los Mercados y Las Necesidades Del Mundo. Simposio $50^{\circ}$ Aniversario de la FAO. En: Revista Agroalimentaria No. 2, 1996. Caracas. 
"interdependencia" e "integración" entre todas las economías ${ }^{12}$, los países dominados aspiran ingenuamente a participar de las ganancias no sólo mediante la explotación de sus "ventajas comparativas" (los cuantiosos ejércitos de desempleados ávidos de ganar salarios de miseria, acceso incondicional a sus recursos naturales, etc.), sino también compitiendo a brazo partido entre sí por pírricas inversiones de los emporios globales. Sin importar que sus propios pueblos se mueran de hambre o que la profundización de la miseria pueda constituirse en amenaza potencial a sus intereses, los sectores atados a la tierra y al capital burocrático en casi todas las naciones atrasadas hacen lo indecible por participar, vía las plataformas de exportación y las economías de enclave, en los beneficios de la globalización de los mercados.

\subsubsection{Las tendencias actuales del comercio: obstáculo a la seguridad alimentaria de los países pobres}

Al lado de los problemas económicos que ocuparon la atención durante los años ochenta, en la dinámica del comercio mundial agroalimentario del nuevo siglo adquieren, por otra parte, una gran relevancia las negociaciones y acuerdos tomados durante la Ronda de Uruguay del GATT (1986-1994) lo mismo que las negociaciones en el marco de la Organización Mundial del Comercio (OMC) desde 1995.

Efectivamente, a la par con los programas neoliberales de ajuste, los acuerdos comerciales impuestos por los países desarrollados han contribuido al estancamiento de la agricultura de alimentos básicos en los países pobres, porque generalmente se "concerta" bajo condiciones desiguales no solamente de producción sino también de comercialización. Al aplicarse el grueso de las barreras arancelarias en el marco de la Política Agrícola Común, por ejemplo, los productos que constituían las tres cuartas partes del valor de las importaciones agrícolas de la Unión Europea se redujeron y afectaron a las exportaciones de los países latinoamericanos. Para los productos agrícolas se emplearon gravámenes $\mathrm{y}$ derechos variables, los precios de referencia (cuyo incumplimiento puede ocasionar la imposición de derechos compensatorios), las licencias y las

12 Sobre este tipo de conceptualizaciones, véase, por ejemplo: Lawrence, R. Z.; A. Bressand, (1995): A Vision for the World Economy: Openness, Diversity, and Cohesion, Washington: The Brookings Institute.

28 Jaime Bonilla-Godoy 
restricciones "voluntarias" de las exportaciones..$^{13}$

En otra dirección, la pérdida de mercados para algunos de los principales productores-exportadores y la rivalidad entre las potencias y bloques imperialistas son razones más para temer por los efectos que provienen de la agresividad de las importaciones. En 1993, por ejemplo, junto al conflicto comercial entre Estados Unidos y la antigua CEE en el Pacífico asiático, y gracias a la revaluación del yen, los bajos salarios y la riqueza de recursos en la región, los inversionistas japoneses de las grandes corporaciones transnacionales optaron por diversificar sus inversiones hacia la producción y comercio de alimentos $\mathrm{y}$ materias agrícolas. El argumento de querer dejar de depender de Estados Unidos en estos rubros significó no sólo nuevos y más agresivos capitales en el mercado mundial de alimentos, sino la reacción de los viejos (Estados Unidos) en sus áreas de influencia ante la pérdida de esos mercados para sus cereales y productos agropecuarios subsidiados. ${ }^{14}$

Así, las frecuentes luchas comerciales entre capitales de los países imperialistas por la hegemonía alimentaria se han dado con base en el concepto de autosuficiencia alimentaria que, por una parte, determina sus políticas agrícolas. Para ellos, tal concepto es una fuente de acumulación (interna y externa) y un elemento estratégico de soberanía $y$, en consecuencia, una cuestión de su seguridad nacional justo en tiempos que muchos autores de la globalización anuncian el fin del Estado-Nación. Pero, por otra parte, la dinámica de la acumulación liderada por esos países no aplica ese concepto de autosuficiencia para los países dominados sino que lo ha roto y "revaluado" dramáticamente. Con la implementación brutal de las reformas neoliberales durante los noventa en los países dominados, los conceptos de "seguridad alimentaria" y las políticas "autosuficiencia y soberanía alimentaria"

13 Derechos variables se aplicaron a las importaciones de ciertos productos agrícolas elaborados. En cambio, los precios de referencia se impusieron a las frutas, legumbres, vino, semillas y pescado. Las restricciones voluntarias de las exportaciones correspondieron a las compras comunitarias de carne ovina y caprina, y para las que se concertaron acuerdos con Argentina, Chile y otros países, a cambio de limitar los envíos que recibían preferencias arancelarias. Los productos tropicales provenientes de América Latina, África y Asia resintieron particularmente los impuestos selectivos y las restricciones cuantitativas. Fue el caso del banano cuyas exportaciones centroamericanas, panameñas y sudamericanas a Francia y al Reino Unido se sujetaron a cuotas reservadas preferentemente a las exportaciones de sus ex colonias del Caribe y África. Como referente de esta misma práctica, vale la pena mencionar las importaciones de flores que se sometieron a medidas de vigilancia que requerían de licencias de concesión automática. Al respecto, véase: González Rubí, R. (1991). "Sección latinoamericana", en Comercio Exterior. Vol. 41, Núm. 6. Bancomext, México; Green, R. (1989). "El comercio agroalimentario mundial y las estrategias de las trasnacionales", en Comercio Exterior, Vol. 39, Núm. 8, agosto. Bancomext, México, y Bonilla-Godoy, J. (1999): The Spatiality of Accumulation during the 1990s. Case Studies on the Colombian Agriculture. Tesis de DPhil. University of London, United Kingdom.

14 LLAMBÍ, L. (1993). "Reestructuración mundial y sistemas agroalimentarios. Necesidad de nuevos enfoques", en Comercio Exterior, Vol. 43, Núm. 3. Bancomext, México. 
fueron abandonados y remplazados por los de "competitividad" y por la orientación del sistema productivo hacia las exportaciones, las panaceas de la época a los profundos desarreglos el desarrollo capitalista. De una y otra aplicación del criterio de autosuficiencia alimentaria se deriva que la posición de los países del norte sea destinar subsidios importantes a la agricultura aún cuando resulte costosa, mientras en la mayoría de los países pobres se optó por su abolición y por la liberalización total de mercados. ${ }^{15}$

Frente a los cada vez más grandes obstáculos que surgen tanto en las negociaciones como en las políticas que se implementan con más fuerza cada vez, es preciso enfatizar que el futuro de la oferta agregada de alimentos solo puede mejorar si los pueblos son capaces de forzar cambios radicales en las estructuras económicas de sus naciones y en la relación entre las naciones. Basado en la perspectiva del desarrollo sostenible y el ser humano como el centro de las estrategias de progreso, sólo un nuevo orden podrá mantener la producción agrícola al ritmo del crecimiento poblacional, la urbanización y los cambios en los patrones de consumo alimentario.

Estos cambios requerirán necesariamente la transformación de los patrones de acceso, propiedad y uso de la tierra - para abolir el latifundio y otras formas de monopolio de la tierra, uno de los mayores obstáculos al desarrollo agrícola- y el capital, lo mismo que cambios fundamentales en las prácticas de protección, acceso, uso y manejo de recursos de la biodiversidad y del ambiente natural, el avance de la investigación agrícola y la aplicación de tecnologías limpias de producción, y una radical redefinición de las prioridades que se basen no en la "competitividad" o en las exportaciones, sino en las necesidades reales de los millones de seres humanos que hoy sufren de hambre.

Al respecto, diversas proyecciones realizadas en 1995 sugerían que, por ejemplo, la inversión en investigación tendrá que ser superior a la de finales de los ochenta para que la producción mundial de granos crezca a 1.5 por ciento anual en el periodo 1995-2020, tasa que sería suficiente para aumentar la disponibilidad per cápita de alimentos y acelerar la reducción de precios reales de la mayoría de los productos alimenticios, incluyendo también los de procesamiento semi-industrial. ${ }^{16}$

Este problema se complica aún más si se examinan las tendencias de la producción y comercio mundial de alimentos controladas por eficientes y subsidiados productores de los países ricos, por el

\footnotetext{
15 Véase al respecto, Chauvet, M. (1994). "Los flancos expuestos de la seguridad nacional: la soberanía alimentaria y la bioseguridad". En: Sociológica. Año 9, Núm. 25.

16 Véase: International Food Policy research Institute (IFPRI) y Rosegrant, Agcaoili-Sombilla y Pérez, 1995.
}

30 Jaime Bonilla-Godoy 
capital financiero y las corporaciones transnacionales. La paradoja de la situación surge al analizar la evolución de las negociaciones mundiales en el GATT y la OMC sobre la abolición de subsidios y barreras para ampliar la libertad de comercio.

A pesar del creciente rechazo de las masas del mundo a la globalización, la preeminencia de tales tendencias -referidas como el inicio de una gobernabilidad global ${ }^{17}$ que se extiende también a la política y al aparato jurídico después de la caída del Muro de Berlín, guerra del Golfo Irak y la desintegración de Yugoslavia ${ }^{18}$ - no parecen apuntar hacia transformaciones importantes $-\mathrm{y}$ ni siquiera notables- en la actual división internacional del trabajo ni en la reinante inequidad en la distribución de la riqueza mundial ni, menos aún, en las políticas o programas de provisión de alimentos para los más pobres.

En efecto, si como resultado de la protesta creciente y masiva contra la globalización en todas las esquinas del globo, y muy especialmente contra las organizaciones internacionales que sirven al gran capital transnacional, los países imperialistas -donde se concentran los más grandes logros en la productividad agrícola e industrial- fueran obligados a reducir y desmontar paulatinamente los subsidios a los productores y demás gabelas de

17 El debate sobre las implicaciones de la supuesta desaparición del Estado Nacional ante el embate de la globalización y cómo surgen nuevas formas e instituciones que buscan una gobernabilidad global por encima de las naciones, existen distintos puntos de vista. Este sería el caso de la Organización de las Naciones Unidas y la alianza militar bajo la Organización del Tratado del Atlántico Norte (OTAN) después de la Guerra del Golfo y de las guerras de Rwanda, Croacia, Bosnia y Kosovo; pero también alude al papel del Fondo Monetario Internacional y el Banco Mundial que determinan más intensamente las políticas económicas de todos los países. El debate alude a que esa gobernabilidad se ejemplificaría mejor con la importancia de la Organización Mundial del Comercio (OMC) paradigma institucional de las tendencias de la globalización. Finalmente, este debate se refiere al papel de la llamada "sociedad civil" global, representada por el papel cada vez más activo de las Organizaciones No Gubernamentales (ONGs). Al respecto, véanse los trabajos de LUBBERS, Ruud, 1998: Fragmented Society, Discurso pronunciado ante el European Forum, Alpbach. LUBBERS, Ruud y KOOREVAAR, Jolanda, 1998: The Dynamic of Globalization (1) y Nation State and Democracy in the Globalizing World (2), Papers presentados en el Seminario sobre Globalización de la Universidad de Tilburg, Holanda. Véanse también: United Nations Research Institute for Social Development, 1996. States of Disarray: The Case Against the Global Economy, ed. Jerry Mander and Edward Goldsmith, Sierra Club Books, San Francisco, 1996; HIRST, Paul y THOMPSON, Grahame, 1996: Globalization in Question, Polity Press, Cambridge; R.F.M. Lubbers, 1996: Globalization, An Exploration. Artículo publicado en Nijenrode Management Review, no.1, November, Holanda y puede consultarse en URL: http//: www.globalize.org. Un importante referente para el análisis y el debate es el Foro Internacional sobre la Globalización donde se expresan puntos de vista muy diversos. Este se puede consultar en el URL: http:// www.panix.com.

18 Examínese, por ejemplo, los documentos de las diversas organizaciones, principalmente de los países ricos, participantes en las protestas contra la globalización en Seatle cuando se realizaba la reunión de la OMC en 1999, las convocatorias y efectos de las acciones directas en el Global Economic Forum en Tokio y durante la Asamblea General de las Naciones Unidas en agosto de 2000. Véanse también los informes sobre las protestas en Praga a propósito de la Reunión Conjunta del Fondo Monetario Internacional y el Banco Mundial en septiembre de 2000. 
precios que están en la base de la superproducción de alimentos en Europa y Estados Unidos, la oferta mundial alimentaria se reduciría dramáticamente $\mathrm{y}$, como manda la lógica de la acumulación imperante, los precios aumentarían escalonadamente. Aunque esto seguramente tardará algunos años y no vislumbrándose alternativas de rescatar la soberanía y autosuficiencia en los países oprimidos, esa mera posibilidad sugiere que la inseguridad alimentaria mundial cobrará no sólo nuevos millones de víctimas, sino una situación peligrosa y explosiva para las capas más frágiles que hoy se encuentran en el límite crítico de la inseguridad alimentaria. ${ }^{19}$

En este mismo sentido, es motivo de incertidumbre creciente el papel que jugarán tanto China como los países del antiguo bloque oriental en las proyecciones globales de oferta y demanda alimentarias. Como puede notarse en los cuadros No.1 a 3 y por la importancia poblacional y económica actual de China, es claro que cualquier cambio dramático en ese país alterará rápidamente la economía alimentaria mundial. En el caso de la Europa del Este y los países de la antigua URSS, es previsible que, en el mediano plazo, entren a jugar un papel importante en el mercado alimentario cuando logren superar la transición y pasen, de importadores netos a dinámicos y competitivos exportadores de cereales y otros alimentos a todo el mundo. Es muy probable que estos países entren a complicar decididamente la posición de muchas economías pequeñas que hoy, con la ilusión de mejorar sus ingresos, se vuelcan al mercado internacional. De allí también provendrán grandes complicaciones para resolver el problema de la seguridad alimentaria de los países pobres donde reside, como se ha visto, la mayor cantidad de personas con desnutrición y subalimentación crónicas. ${ }^{20}$

El panorama mundial de la inseguridad alimentaria y los factores que 10 determinan son inaceptables desde cualquier punto de vista. La evolución reciente de las economías semicoloniales no parece apuntar en la perspectiva de alcanzar la soberanía, autosuficiencia y seguridad alimentaria y su progreso equilibrados que tengan como base las necesidades de sus pueblos. De hecho, comenzando el año 2000, la situación de la oferta global de alimentos no es nada promisoria en ninguna de las regiones oprimidas del mundo. En particular, la situación del África Subsahariana, el Norte de África, el Medio Oriente, el Sur

\footnotetext{
19 Las negociaciones del GATT redujeron los subsidios en la Unión Europea y Estados Unidos pero su implementación era, a finales de 1999, aún mucho más lenta que lo previsto en la Ronda Uruguay finalizada hace seis años. Sin embargo, ese acuerdo probablemente presionará el alza de los precios de alimentos

20 Observadores del mercado mundial de alimentos infieren que los países de Europa del Este y de la Antigua Unión Soviética incrementarán considerablemente la oferta de alimentos en los próximos diez años (Tyers, 1994), lo que, por un lado, representará una disminución de los precios pero, por otro, será un fuerte elemento de competencia con los países del llamado tercer mundo.
}

32 Jaime Bonilla-Godoy 
de Asia y América Latina y el Caribe es motivo de extrema preocupación. ${ }^{21}$

En lo que sigue examinamos con detalle la situación de América Latina y el Caribe para ilustrar los efectos devastadores de la reciente evolución de la economía mundial de alimentos y las contradicciones que atañen a la cuestión alimentaria.

\subsection{Una referencia a la situación alimentaria de América Latina y el Caribe}

Entre la quinta parte de los habitantes del planeta que no recibe la cantidad suficiente de nutrientes para cumplir con las necesidades básicas de supervivencia, América Latina y el Caribe (en adelante ALC) representan un gran porcentaje. Hasta comienzos de los noventa, la población desnutrida en ALC había venido disminuyendo significativamente en términos relativos (de 19 a 13 por ciento de la población total entre 1969-71 y 1988-91). Sin embargo, la cantidad efectiva de personas en esa situación no dejó de aumentar $\mathrm{y}$, a pesar de algunos progresos y del crecimiento y transformaciones económicas, en el lapso de menos de 20 años desde el inicio de la "crisis de la deuda", la región registró un aumento de 14 millones de personas con hambre. Para comienzos de 1991, esa cifra representaba un total de 59 millones de personas en la miseria absoluta y para finales de 1999, ascendía a 64 millones.

Como hemos aludido insistentemente a lo largo de este ensayo, la producción mundial de alimentos no ha dejado de aumentar en los últimos años y el mundo está en condiciones de producir alimentos suficientes para todos. El asunto que explica la persistencia de la desnutrición en ALC no es, fundamentalmente, un problema de producción deficitaria ni, como sostienen algunas corrientes neomaltusianas, la presión demográfica sobre los recursos que, sin duda, es relativamente alta a pesar de los progresos recientes. El asunto central es la inequitativa distribución de la riqueza, la apropiación de excedentes por fuera de la región y la mercantilización de todas las actividades productivas, particularmente la de la producción, procesamiento y distribución de productos alimenticios. El cuadro No. 4 muestra la evolución de la producción de alimentos en la segunda parte del siglo XX en América Latina y el Caribe:

$\overline{21}$ Véanse, al respecto, los informes consecutivos del FIVIMS (Food Insecurity and Vulnerability Information and Mapping Systems) y UNITED NATIONS-FOOD AND AGRICULTURE ORGANIZATION, (1999): The State of Food Insecurity in the World, Washington. 
Cuadro No. 4

Evolución de la Provisión de Alimentos en América Latina y el Caribe, 1965-1995

\begin{tabular}{|c|c|c|c|c|}
\hline Quinquenio & $\begin{array}{c}\text { Producción total } \\
\text { de alimentos } \\
\mathbf{1 9 8 9 - 9 1 = 1 0 0}\end{array}$ & $\begin{array}{c}\text { Producción } \\
\text { per cápita } \\
\mathbf{1 9 8 9 - 9 1 = 1 0 0}\end{array}$ & $\begin{array}{c}\text { Exporta- } \\
\text { ciones } \\
\text { (US millones) }\end{array}$ & $\begin{array}{c}\text { Importa- } \\
\text { ciones } \\
\text { (US \$ millones) }\end{array}$ \\
\hline $1960-1965$ & 52.5 & 93.1 & 6.070 & 1.753 \\
$1965-1970$ & 60.0 & 93.0 & 7.641 & 2.300 \\
$1970-1975$ & 67.8 & 92.3 & 17.340 & 6.170 \\
$1975-1980$ & 80.5 & 95.7 & 31.991 & 14.525 \\
$1980-1985$ & 92.6 & 96.1 & 30.991 & 10.253 \\
$1985-1990$ & 99.6 & 101.1 & 35.380 & 14.747 \\
$1990-1995$ & 111.2 & 97.7 & 39.895 & 23.005 \\
\hline
\end{tabular}

Fuente: FAOSTAT, 1996.

Como puede apreciarse, los desarrollos económicos presenciados por la región en el periodo referido llevaron a que el índice de producción total de alimentos se duplicara en los últimos 40 años, aunque la producción per cápita no mostraba el mismo comportamiento por el aumento poblacional que sólo durante los noventa empezaba a estabilizarse. No obstante, el factor que estuvo en la base de ese desarrollo fue el desarrollo del llamado sector "moderno" de la agricultura dirigido primariamente hacia los mercados externos y la imposición del modelo agroexportador particularmente después de la segunda mitad de los ochenta.

Las exportaciones agrícolas de la región se multiplicaron 5 veces entre 1970 y 1994, pasando de 7.6 a 39.9 mil millones de dólares, y están constituidas en su mayoría por productos tradicionales, cuyos precios presentan grandes fluctuaciones en los mercados internacionales, primando la tendencia a la baja, aspecto que aumenta la vulnerabilidad de estas economías dependientes. Las exportaciones no tradicionales han registrado un aumento pero siguen representando una parte mínima del total de exportaciones agrícolas. Las importaciones, por su parte, pasaron de 2.3 a 23 mil millones de dólares en el mismo periodo, representando una aumento de diez veces. Así, aunque en 1994, América Latina y el Caribe exportaban, en términos de valor, más de lo que importaban (39.9 y 23 mil de millones de dólares respectivamente), la tendencia indica que rápidamente se acercaba a un equilibrio crítico y muchos de los países adquirían una condición de importadores netos. Esto ocurriría después de 1995 cuando las reformas internas de todas las economías tomaron visos dramáticos, particularmente para su sector agrícola. 
El aumento de las exportaciones agrícolas ha generado importantes divisas a nuestras economías. A pesar de esto, más millones de campesinos y sectores de ingresos ínfimos en áreas rurales y ciudades latinoamericanas sufren hambre y desnutrición, más niños menores de cinco años mueren cada año por cuenta de enfermedades propias de la pobreza y los salarios de los trabajadores son inferiores a los niveles mínimos de sobrevivencia. Estas realidades evidencian que, a pesar de que la tendencia de la producción agrícola es hacia el crecimiento, ésta va pareja al aumento del hambre y la exclusión social en todo el mundo "en desarrollo". Los sectores más dinámicos, particularmente los de la agricultura comercial (o moderna) no parecen actuar como correa de transmisión para un mayor bienestar de los pobladores rurales, y menos aún demuestran un nivel redistributivo de la riqueza que garantice un mayor desarrollo de las masas de campesinos y de sectores urbanos pobres. ${ }^{22}$

Es importante resaltar que, como resultado de las negociaciones comerciales en el marco Ronda Uruguay del GATT, y de los programas de reestructuración "aconsejada" en los noventa por las agencias internacionales (FMI y Banco Mundial) como parte de sus términos de condicionalidad para la asignación de nuevos créditos de fomento, la liberalización de la agricultura constituyó eje principal en la mayoría de los países de la región. Aunque vale precisar que, como resultado de la recesión generalizada de la mayoría de las economías de la región después de 1995, las importaciones de bienes, incluyendo las de origen agrícola, eran mayores y seguían creciendo más rápido que las exportaciones como lo muestra la gráfica siguiente:

Basados en la nueva "verdad" de que era urgente abrir las fronteras, suprimir cualquier obstáculo y distorsión al libre comercio y liberalizar los precios agrícolas, la mayoría de economías de ALC suprimió los aranceles y demás trabas a las importaciones, dejando en una situación de desprotección y crisis a numerosos productores agrícolas. Como ocurre cuando hay colisión de capitales de distinta naturaleza, los productores más dinámicos, de mayor poder adquisitivo, de

22 De acuerdo a diversos estudios en 12 de los países más grandes que representan 71 por ciento de la población, la pobreza afectaba en 1996 a 36.7 por ciento de los habitantes, mientras que la pobreza extrema, definida como la incapacidad para adquirir los requerimientos alimenticios básicos, afectaba a 1 de cada 6 habitantes. La población con ingreso per cápita inferior al de la línea de extrema pobreza alcanzaba la cifra de 16.1 por ciento. Aunque estos estudios registran un progreso en el combate a la pobreza, principalmente, por la evolución del Brasil entre 1992 de 1996, se evidencia también que los niveles de pobreza y miseria en 1996 eran mayores que 10 años antes cuando los registros eran de 35.7 y 13.3 por ciento respectivamente. Como concluyen los aludidos estudios, la recuperación leve de varios países de la región durante los noventa y la reducción de la pobreza no ha sido suficiente para compensar los efectos dramáticos de la "década perdida" de los ochenta. Sobre esto, véanse los estudios de Londoño y Szekely (1997), Mejía y Vos (1997), PSACHAROPOULOS et al. (1997), Ganuza, Taylor y Morley (1998), CEPAL (1999), y Szekely et al. (1999). 
Gráfico 1.3

América Latina y el Caribe - Comercio de Bienes a/

(En miles de millones de dólares)

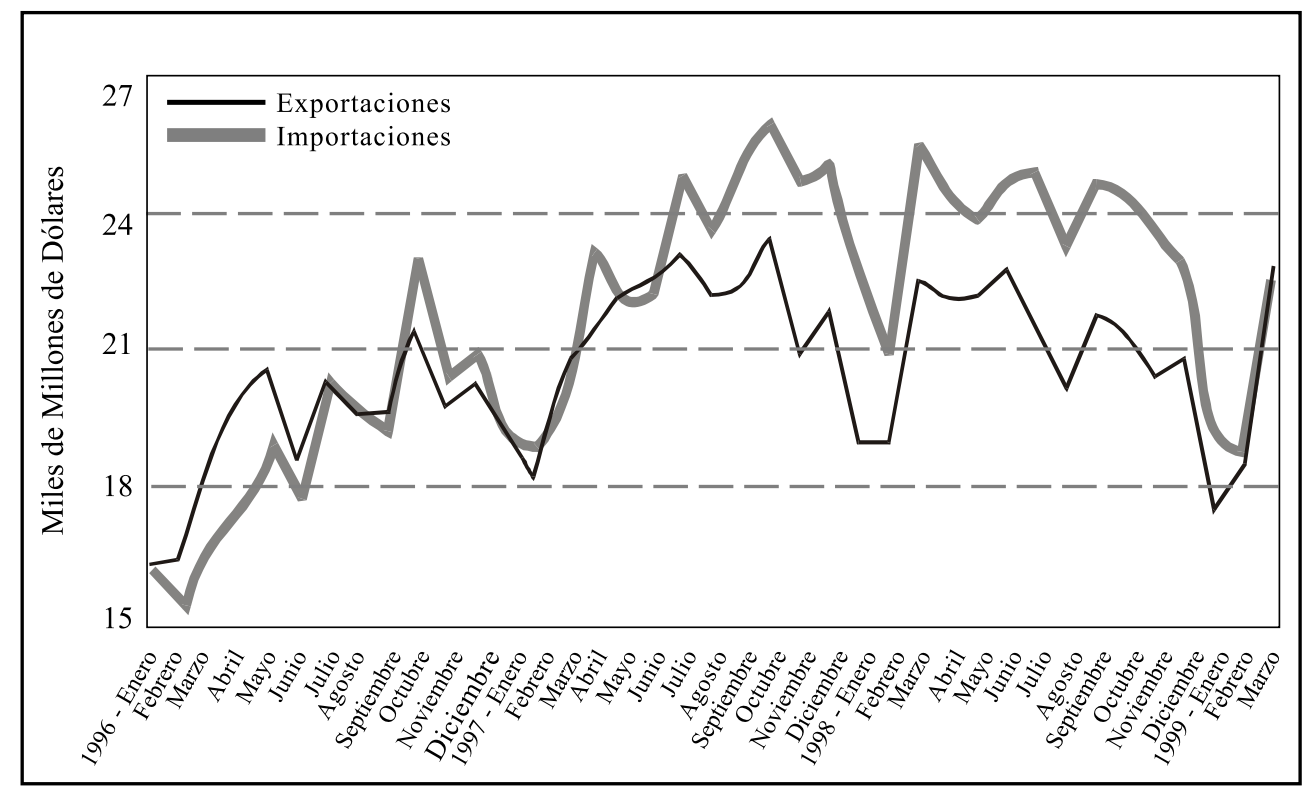

Fuente: CEPAL, sobre la base de cifras oficiales.

a/ Incluye Argentina, Bolivia, Brasil, Chile, Colombia, Costa Rica, Ecuador, México, Paraguay, Perú, Uruguay y Venezuela.

mayor capacidad de competir y/o integrados en algún eslabón a las corporaciones transnacionales de alimentos, salieron fortalecidos de semejante proceso y elevaron su capacidad de exportar. Otros productores, menos eficientes y endeudados, acaso sobrevivieron dirigiéndose a los menguados mercados internos. Muchos, no obstante, no sólo no sobrevivieron al nuevo modelo sino que, como ha ocurrido con miles de campesinos tradicionales, debieron abandonar sus parcelas y pasaron a engrosar las áreas urbanas deprimidas, quedaron desempleados o se vincularon al creciente ejército de trabajadores informales e indigentes en las ciudades latinoamericanas.

El cuadro No. 5 muestra la evolución e incidencia de la pobreza y la extrema pobreza durante los noventa en los 12 países más grandes de ALC que representan el 71 por ciento de la población de la región: 
Cuadro No. 5

Incidencia de la Pobreza y la Pobreza Extrema en Latinoamérica y el Caribe, 1986-1996

\begin{tabular}{|c|c|c|c|c|c|c|c|c|c|c|c|}
\hline & & \multicolumn{4}{|c|}{ Incidencia de la Pobreza } & \multicolumn{3}{|c|}{ Incidencia de la extrema Pobreza } \\
\cline { 3 - 11 } Año & $\begin{array}{c}\text { Poblac. } \\
\text { total } \\
\text { (mill.) }\end{array}$ & $\begin{array}{c}\text { Total } \\
\text { pobres } \\
\text { mill. }\end{array}$ & $\begin{array}{c}\text { Indice } \\
\mathbf{1} *\end{array}$ & $\begin{array}{c}\text { Indice } \\
\mathbf{2} * *\end{array}$ & $\begin{array}{c}\text { Poverty } \\
\text { Gap 1 }\end{array}$ & $\begin{array}{c}\text { Poverty } \\
\text { Gap 2 }\end{array}$ & $\begin{array}{c}\text { Total } \\
\text { pobres } \\
\text { extrem. }\end{array}$ & $\begin{array}{c}\text { Indice } \\
\mathbf{1} *\end{array}$ & $\begin{array}{c}\text { Indice } \\
\mathbf{2} * *\end{array}$ & $\begin{array}{c}\text { Poverty } \\
\text { Gap 1 }\end{array}$ & $\begin{array}{c}\text { Ext. } \\
\text { Poverty } \\
\text { Gap 2 }\end{array}$ \\
\hline 1986 & 407.38 & 137.49 & 33.75 & 43.63 & 14.84 & 22.34 & 54.26 & 13.32 & 21.98 & 5.94 & 11.44 \\
1989 & 430.98 & 164.89 & 38.26 & 43.76 & 18.18 & 21.67 & 75.81 & 17.59 & 21.01 & 8.02 & 10.48 \\
1992 & 454.65 & 180.27 & 39.65 & 42.34 & 19.20 & 20.46 & 84.79 & 18.65 & 19.73 & 9.10 & 9.38 \\
1995 & 478.21 & 176.56 & 36.92 & 42.82 & 17.00 & 20.26 & 76.23 & 15.94 & 19.30 & 7.20 & 8.73 \\
1996 & 486.06 & 178.58 & 36.74 & 40.25 & 16.93 & 18.49 & 78.26 & 16.10 & 17.34 & 7.38 & 7.86 \\
\hline
\end{tabular}

* Indice 1 medido sobre la población y peso relativo de cada país.

** Indice 2, medido sobre el promedio de cada país con ponderación (peso igual) por país.

Fuente: World Bank, (1998).

Entre los ganadores, los sectores modernos ligados al capital transnacional siguen siendo hoy los principales defensores del nuevo modelo que avanza en la conversión del sector agrícola en plataformas de exportación y enclaves de producción y procesamiento para los mercados de alimentos de las metrópolis ricas. Esos mismos sectores son también los que han amasado fortunas extraordinarias con la creciente exportación de alimentos hacia los países oprimidos.

Además de la liberalización comercial, las continuas disputas comerciales entre las economías cabeza de bloque habían hecho que Estados Unidos, la nación con la más alta competitividad, hubiera optado por incrementar sus exportaciones de alimentos a la región, encontrando en el déficit productivo reciente el ambiente propicio para colocar su producción agrícola sobrante como probablemente sucederá con la protocolización del ALCA luego de las recientes negociaciones en Quebec. En el lado de las exportaciones, la región tampoco ha podido capitalizar éxitos significativos como lo ha predicado el modelo neoliberal recién implantado. Como se sabe, aparte de unas pocas prebendas para algunos pocos países (particularmente las exenciones del ATPA concedidas a los países productores de cocaína para reducir la exportación de esa sustancia), el acceso a los mercados de los países ricos es restringido por diversos aranceles y demás medidas proteccionistas. El SGP (Sistema General de Preferencias) de la Unión Europea y de los Estados Unidos prevé facilidades en términos de 
asignación de cuotas y de cancelación de aranceles, pero los países y los sectores privilegiados por esos sistemas son escogidos celosamente, de tal manera que no compitan con los productores locales. $^{23}$

Esta situación revela una paradoja de doble implicación: primero, a pesar de que la ideología del libre comercio suele definirse de manera unívoca y clara -en términos de abolición de restricciones y eliminación de medidas proteccionistas-, éste se aplica en forma discriminada, en beneficio de los grandes intereses económicos que dominan la Organización Mundial del Comercio y otras agencias, en lo que el lenguaje popular llama "la ley del embudo". Y, segundo, que con la reestructuración neoliberal iniciada en la segunda mitad de los ochenta -que prometía mejoras fundamentales de la producción y el nivel de vida-, los ritmos de crecimiento de la agricultura y de toda la economía latinoamericana en los noventa decayeron dramáticamente $\mathrm{y}$ devinieron insuficientes para mejorar la situación existente y estimada de inseguridad alimentaria de la región.

Según la FAO, esta situación es el resultado de factores como la reducción del área cultivable, que aminora los efectos positivos de los aumentos de la productividad alcanzados, la sobrevaluación de las tasas de cambio (que perjudica las exportaciones nacionales), la reducción del apoyo público al sector, principalmente a la agricultura tradicional que surte la mayoría de alimentos en el continente, el aumento del costo de los créditos, y las políticas monetarias y fiscales restrictivas. Para la FAO esta situación es, categóricamente, inaceptable. ${ }^{24}$ El cuadro No. 6 muestra el pobre desempeño de la agricultura en ALC.

Además de estas razones reconocidas por FAO se agregan otros procesos que complican la cuestión de la seguridad alimentaria.

a) Los motores del escaso crecimiento en la región durante los noventa son la industria y los servicios; empero, si bien son esenciales para el desarrollo, éstos no proveen de alimentos a la población latinoamericana, y aumentan en forma inquietante las condiciones y síntomas del hambre;

b) La creciente marginación de los campesinos medios y pobres y de regiones agrícolas que no satisfacen los criterios de competitividad del modelo, expone a esos sectores y regiones a la competencia con el capital asociado de las corporaciones transnacionales y los propietarios de tierras, altamente asistidos

\footnotetext{
${ }_{23}$ Sobre el papel de los subsidios a la agricultura de alimentos, véase: León, A. y Guzmán, E. (1997). "Soberanía y heterogeneidad: tres décadas de financiamiento a la agricultura europea", en Cuadernos agrarios, nueva época, Núm.15, México; y Bonilla-Godoy, J. Op. Cit.

24 Véase, ORGANIZACIÓN DE LAS NACIONES UNIDAS PARALAAGRICULTURAY LAALIMENTACIÓN, FAO, (2000).
} 
(incluso con subsidios y créditos blandos) por el Estado y cuyas formas de organización de la producción y la comercialización (a través de empresas comerciales e hipermercados altamente centralizados) restringen la competencia de pequeños productores. De hecho, esta es una de las razones que explica la creciente disminución de la oferta de alimentos destinados al consumo de las grandes mayorías urbanas de bajos ingresos;

c) Por su carácter, las medidas de política que materializan el nuevo modelo en el objetivo de dinamizar las economías nacionales vía plataformas de exportación $\mathrm{y}$ enclaves productivos, no garantizan el incremento de la productividad y la competitividad. Como se sabe, el elemento sobre el que evolucionan tales políticas no plantea la transformación de la estructura monopólica de propiedad y uso de la tierra, y tampoco tiene en cuenta prioridades fundamentales de carácter nacional, tales como la satisfacción de las necesidades básicas de la población y la generación de un mercado interno capaz de dinamizar el resto de la economía.

Finalmente, la paradoja se expresa en una situación que desde cualquier perspectiva resulta devastadora: mientras más y más campesinos abandonan el campo, el grueso de la población urbana debe padecer hambre y desnutrición crónica. 
Cuadro No. 6

Evolución del Sector Agrario en América Latina y Comparación con el resto del mundo

\section{Crecimiento Anual Promedio, 1980-1997 (\%)}

\begin{tabular}{|c|c|c|c|c|c|c|c|c|c|c|c|c|}
\hline \multirow{3}{*}{ País o Región } & \multicolumn{3}{|c|}{ Población Rural } & \multicolumn{3}{|c|}{ Superf. Cultivable } & \multicolumn{4}{|c|}{ Uso de la tierra } & & \\
\hline & \multicolumn{2}{|c|}{$\begin{array}{l}\% \text { del } \\
\text { total }\end{array}$} & \multirow{2}{*}{\begin{tabular}{|c|}
$\begin{array}{c}\text { Crecim. } \\
\text { anual } \\
\text { promed. } \\
\%\end{array}$ \\
$1980-98$
\end{tabular}} & \multirow{2}{*}{\begin{tabular}{|c|}
$\begin{array}{c}\text { Super- } \\
\text { ficie } \\
\text { total } \\
(\mathrm{miles} \\
\left.\text { de } \mathrm{km}^{2}\right)\end{array}$ \\
1997 \\
\end{tabular}} & \multicolumn{2}{|c|}{$\begin{array}{c}\text { Tierra } \\
\text { Arable } \\
\text { (\% de } \\
\text { superficie } \\
\text { total) }\end{array}$} & \multicolumn{2}{|c|}{$\begin{array}{l}\text { Cultivos } \\
\text { Perman. } \\
\text { (\% de la } \\
\text { superficie } \\
\text { total) }\end{array}$} & \multicolumn{2}{|c|}{$\begin{array}{l}\text { Otros usos } \\
\text { (\% de la } \\
\text { superficie } \\
\text { total) }\end{array}$} & \multicolumn{2}{|c|}{$\begin{array}{l}\text { Crecim. } \\
\text { anual del } \\
\text { producto } \\
\text { agrícola } \\
(\%)\end{array}$} \\
\hline & 1980 & 1998 & & & 1980 & 1997 & 1980 & 1997 & 1980 & 1997 & 1980 & 1997 \\
\hline Argentina & 17 & 11 & -1.2 & 2737 & 9.1 & 9.1 & 0.8 & 0.8 & 90.1 & 90.1 & 0.7 & 3.4 \\
\hline Bolivia & 55 & 39 & 0.3 & 1084 & 1.7 & 1.7 & 0.2 & 0.2 & 98.1 & 98.1 &.. &. \\
\hline Brasil & 34 & 20 & -1.3 & 8457 & 4.6 & 6.3 & 1.2 & 1.4 & 94.2 & 92.3 & 2.8 & 3.1 \\
\hline Chile & 19 & 15 & 0.4 & 749 & 5.1 & 2.6 & 0.3 & 0.4 & 94.6 & 96.9 & 5.9 & 1.2 \\
\hline Colombia & 36 & 27 & 0.4 & 1039 & 3.6 & 1.9 & 1.4 & 2.4 & 95.0 & 95.7 & 2.9 & -3.0 \\
\hline Costa Rica & 57 & 53 & 2.0 & 51 & 5.5 & 4.4 & 4.4 & 5.5 & 90.1 & 90.1 & 3.1 & 2.7 \\
\hline $\begin{array}{l}\text { Cuba } \\
\text { Republica }\end{array}$ & 32 & 25 & -0.6 & 110 & 23.9 & 33.7 & 6.4 & 6.8 & 69.7 & 59.5 &. &. \\
\hline Dominicana & 50 & 36 & 0.3 & 48 & 22.1 & 21.1 & 7.2 & 9.9 & 70.6 & 69.0 & 0.4 & 3.6 \\
\hline Ecuador & 53 & 37 & 0.3 & 277 & 5.6 & 5.7 & 3.3 & 5.2 & 91.1 & 89.2 & 4.4 & 2.7 \\
\hline El Salvador & 58 & 54 & 1.1 & 21 & 26.9 & 27.3 & 11.7 & 12.1 & 61.4 & 60.6 & -1.1 & 0.9 \\
\hline Guatemala & 63 & 61 & 2.4 & 108 & 11.7 & 12.5 & 4.4 & 5.0 & 83.9 & 82.4 & 1.2 & 2.8 \\
\hline Haití & 76 & 66 & 1.1 & 28 & 19.8 & 20.3 & 12.5 & 12.7 & 67.7 & 67.0 & -0.1 & -4.3 \\
\hline Honduras & 65 & 49 & 1.5 & 112 & 13.9 & 15.1 & 1.8 & 3.1 & 84.3 & 81.7 & 2.7 & 2.8 \\
\hline México & 34 & 26 & 0.5 & 1909 & 12.1 & 13.2 & 0.8 & 1.1 & 87.1 & 85.7 & 0.8 & 1.4 \\
\hline Nicaragua & 50 & 45 & 2.1 & 121 & 9.5 & 20.2 & 1.5 & 2.4 & 89.1 & 77.4 & -2.2 & 5.3 \\
\hline Panamá & 50 & 44 & 1.3 & 74 & 5.8 & 6.7 & 1.6 & 2.1 & 92.5 & 91.2 & 2.5 & 2.0 \\
\hline Paraguay & 58 & 45 & 1.5 & 397 & 4.1 & 5.5 & 0.3 & 0.2 & 95.6 & 94.2 & 3.6 & 2.8 \\
\hline Perú & 35 & 28 & 0.7 & 1280 & 2.5 & 2.9 & 0.3 & 0.4 & 97.2 & 96.7 & 2.7 & 5.5 \\
\hline Puerto Rico & 33 & 26 & -0.4 & 9 & 5.6 & 3.7 & 5.6 & 5.1 & 88.7 & 91.2 & 1.8 &.. \\
\hline Trinidad- & 37 & 27 & -0.9 & 5 & 13.6 & 14.6 & 9.0 & 9.2 & 77.4 & 76.2 & -5.8 & 1.8 \\
\hline Venezuela, & 21 & 14 & 0.1 & 882 & 3.2 & 3.0 & 0.9 & 1.0 & 95.9 & 96.0 & 3.0 & 1.1 \\
\hline Mundo & 60 & 54 & 1.0 & 130181 & 10.1 & 10.6 & 0.9 & 1.0 & 66.9 & 88.4 & 2.7 & 1.7 \\
\hline Países Bajos Ingresos & 78 & 70 & 1.2 & 41383 & 11.5 & 12.4 & 0.9 & 1.4 & 87.7 & 86.2 & 4.1 & 3.7 \\
\hline Excl. China e India & 78 & 69 & 1.7 & 28963 & 7.0 & 7.8 & 1.0 & 1.3 & 92.0 & 90.9 & 3.0 & 2.7 \\
\hline Países Ingreso Medio & 44 & 35 & 0.2 & 57873 & 7.1 & 8.7 & 1.2 & 1.0 & 91.7 & 90.3 & 2.7 & 0.8 \\
\hline Ingreso Medio Bajo & 49 & 42 & 0.7 & 36096 & 7.5 & 9.2 & 1.3 & 0.8 & 91.2 & 90.0 &.. & -0.5 \\
\hline Ingreso Medio Alto & 37 & 23 & -0.9 & 21777 & 6.9 & 7.9 & 1.1 & 1.3 & 92.0 & 90.8 & 2.5 & 2.0 \\
\hline Ingreso Medio y Bajo & 68 & 59 & 1.0 & 99257 & 9.4 & 10.3 & 1.0 & 1.2 & 89.5 & 88.6 & 3.4 & 2.2 \\
\hline $\begin{array}{l}\text { Sur Asia Pacífico } \\
\text { Europa y Asia }\end{array}$ & 78 & 66 & 0.6 & 15968 & 10.0 & 12.0 & 1.5 & 2.6 & 88.5 & 85.4 & 4.4 & 3.5 \\
\hline $\begin{array}{l}\text { Central } \\
\text { América Lat }\end{array}$ & 41 & 34 & -0.5 & 23844 & 38.6 & 11.9 & 3.1 & 0.4 & 58.3 & 87.7 &.. & -3.1 \\
\hline $\begin{array}{l}\text { América Latina } \\
\text { y el Caribe } \\
\text { Medio Oriente y }\end{array}$ & 35 & 25 & 0.1 & 20064 & 5.8 & 6.7 & 1.1 & 1.3 & 93.1 & 92.0 & 2.1 & 2.2 \\
\hline Norte de África & 52 & 43 & 1.5 & 10995 & 4.4 & 5.2 & 0.4 & 0.7 & 95.1 & 94.1 & 5.5 & 2.5 \\
\hline Sur de Asia & 78 & 72 & 1.7 & 4781 & 42.5 & 42.4 & 1.5 & 2.1 & 56.1 & 55.5 & 3.2 & 3.7 \\
\hline África Subsahariana & 77 & 67 & 2.0 & 23605 & 5.4 & 6.4 & 0.7 & 0.9 & 93.9 & 92.7 & 2.5 & 2.4 \\
\hline Países Altos Ingresos & 25 & 23 & -0.2 & 30925 & 12.0 & 11.7 & 0.5 & 0.5 & 87.5 & 87.8 &. & 0.8 \\
\hline Europa & 26 & 22 & -0.5 & 2307 & 27.6 & 26.7 & 4.7 & 4.3 & 67.7 & 69.0 &.. & 0.7 \\
\hline
\end{tabular}

Fuente: World Development Indicators 2000. The World Bank.

40 Jaime Bonilla-Godoy 
En otro apartado de este artículo hemos aludido a los impactos de la crisis asiática sobre los países de ALC y cómo ella ha agudizado las condiciones de oferta y demanda alimentaria a lo largo de la región. Efectivamente, la globalización no parece traer tampoco ni el éxito ni los beneficios que se han publicitado con tanta euforia en los medios de comunicación extranjeros y nacionales.

Con el estallido de la crisis, particularmente manifiesta en la caída de los precios y volúmenes de exportaciones de los países especializados en productos agropecuarios tradicionales (café, caña de azúcar, cacao, banano, algodón y frutas exóticas), lo mismo que la descapitalización de la mayoría de las economías "emergentes", los países de ALC vieron caer, de la noche a la mañana, los términos de intercambio en cerca de 4 por ciento, lo que significó pérdidas equivalentes al 0.6 por ciento de su producto bruto en 1998. Los volúmenes de exportación pasaron de 11.5 por ciento en 1997 a 5.6 por ciento en 1998 y la ampliación del déficit de cuenta corriente a 22 mil millones de dólares. ${ }^{25}$

Los efectos combinados de la crisis mexicana de 1994 y asiática en 1997, causaron un deterioro general de los indicadores de desempeño, particularmente un deterioro del Producto Interno Bruto que, para comienzos de 1999, mostraba crecimientos negativos como lo muestra el gráfico No. 1, con efectos adversos en la situación del empleo urbano y rural que, desde comienzos de los ochenta, había venido deteriorándose. Los Anexos 1 y 2 muestran la evolución general del desempleo en ALC durante la década.

Aparte de México, que se benefició del crecimiento de las importaciones norteamericanas y que pudo resolver medianamente los problemas del efecto tequila, el desempeño de las exportaciones de ALC pasó de crecer 9.5 por ciento en 1997 a 3.3 por ciento en 1998 y un empeoramiento paulatino de la competitividad de las mismas. Los países que tenían un control de la tasa de cambio presenciaron una revaluación de sus monedas en cerca de 17 por ciento sobre los niveles promedios de 1990-96 (antes de la crisis asiática), al tiempo que los países asiáticos sufrieron una reducción de 25 por ciento durante el mismo periodo. Estos cambios y la entrada de Rusia en el torbellino provocaron una reducción de 25 por ciento en los flujos de capital entre 1997 y 1998.

El apretón del crédito y el agudo deterioro del déficit de cuenta corriente hicieron imposible que los países de la región, comenzando con Chile, pudieran no solo financiar los efectos del shock comercial, sino también los objetivos de crecimiento económico. Esto y la persistencia de una deuda creciente, generaron dramáticas caídas del producto regional de 5.4 a 2.1 por ciento entre 1997 y 1998 cuando Argentina, Brasil, Chile, Colombia, Ecuador, Perú, y Venezuela iniciaron una nueva

${ }^{25}$ Véase: World Bank, (2000): Global Economic Prospects, 2000. URL, www.worldbank.org. 
recesión que implicó grandes reducciones del ingreso en las capas pobres y medias de la población y el aumento inmediato de la pobreza. En Brasil, Colombia, Ecuador y Venezuela contribuyeron también las altísimas tasas de interés que aumentaron el servicio de la deuda, mayor ajuste fiscal y mayores tasas de desempleo. En el Caribe, el crecimiento de ingreso per cápita se redujo a sólo 2.2 por ciento en 1998-99 y casi todas las economías pasaron a depender totalmente de sus ingresos por turismo. El Anexo 3 muestra las tendencias de largo plazo de los indicadores básicos de la región.

Gráfico I.1

América Latina y el Caribe: Producto Interno Bruto a/

(En porcentajes de variación, con respecto al mismo trimestre del año anterior)

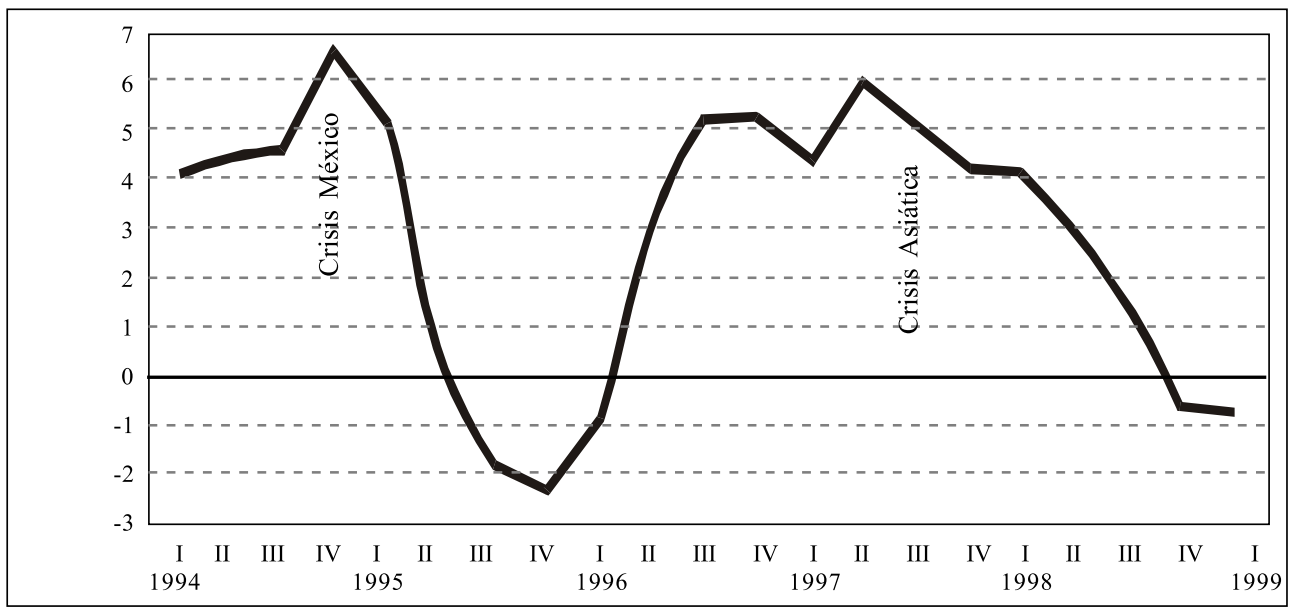

Fuente: CEPAL, sobre la base de cifras oficiales.

a/ Incluye Argentina, Brasil, Chile, Colombia, México, Perú y Venezuela.

Las perspectivas de mejoramiento de la situación económica general, optimistas según estima el Banco Mundial, no esconden el hecho de que la inseguridad alimentaria no sólo no es una prioridad, sino que el propio crecimiento económico está seriamente comprometido como resultado de los impactos de largo plazo de la crisis asiática y de las que están por venir dada la voracidad de los mercados financieros en todo el mundo. Sólo la profundización y la mayor eficiencia de reformas del tipo "sudor y lágrimas" que pregona el gobierno colombiano podrán, en el mediano plazo, recuperar algunos indicadores económicos, aunque ellas signifiquen mayor profundización de la pobreza. ${ }^{26}$

\footnotetext{
${ }^{26}$ Léase, para el caso, el discurso de Michel Camdessus, Repercusiones regionales de la globalización: Una perspectiva latinoamericana.

Presentación de Director Gerente del Fondo Monetario Internacional a la 40a. Asamblea del Banco Interamericano de Desarrollo. París, 15 de marzo de 1999.
}

\section{Jaime Bonilla-Godoy}


Esta es la panorámica de América Latina y el Caribe en la alborada del nuevo milenio. Empero, la situación de inseguridad alimentaria mundial, el hambre y la desnutrición crónica se repite, aún con mayor dureza, a lo largo del sur de Asia, el África Subsahariana y África del norte y de extensas regiones del Centro u Oriente de Asia y de Europa Central.

\section{Biodiversidad y conocimiento asociado: pérdida, expropiación e imposición de nuevas cargas a los países oprimidos}

La satisfacción de las necesidades alimenticias de la mayoría de la población mundial se sustenta hoy en el uso de los recursos de la biodiversidad y en el conocimiento tradicional de las comunidades locales sobre conservación y utilización de plantas, animales, insectos, microbios y sistemas de cultivo. Cerca del 93 por ciento de las necesidades alimentarias de la población mundial proviene de material genético de las plantas, 30 por ciento proviene del consumo de animales (12 por ciento del total de la población depende enteramente del consumo de rumiantes). Entre tanto, más del 80 por ciento de la población mundial satisface sus necesidades con alimentos y medicinas desarrolladas a partir del conocimiento indígena tradicional, y por lo menos la mitad hace uso del conocimiento ancestral de las comunidades nativas para satisfacer sus requerimientos alimenticios. ${ }^{27}$

Con los avances tecnológicos y científicos, el rápido desarrollo de la ciencia y la acción global de capitales y firmas, un conjunto de nuevas y más complejas contradicciones han empezado a emerger en la configuración actual de la economía mundial y las cuales constituyen un obstáculo mayúsculo en la meta de garantizar la seguridad alimentaria mundial. Se trata de un conjunto de procesos y contradicciones que tienen que ver con la lógica de la acumulación a que hemos aludido extensamente en este ensayo.

En el primer aspecto, se refiere a las prácticas de uso y aprovechamiento de los recursos, los patrones de desarrollo y los estilos y formas de vida y consumo que han acelerado la pérdida de la diversidad biológica que sostiene la mayor parte de la población mundial. El segundo refiere a la emergencia de nuevas formas de apropiación, uso y acceso de los recursos genéticos y de la biodiversidad -sometidas, como la producción básica de alimentos, a las leyes de la acumulación de capital- que están en la base de la alimentación mundial. Esta segunda parte intenta abordar algunas de las

27 Véase: Lovejoy, Thomas J., 1994. Biodiversity: The Most Fundamental Issue. Conferencia dictada ante la Academia Australiana de Ciencias. Marzo 1. Transcripción de Australian Academy of Science. Véase también: World Conservation Monitoring Center, 1995. Biodiversity: An Overview. World Wide Web: WCMC. Material de Divulgación. Véase también: Lovejoy, T.J., 1994. The quantification of biodiversity: An esoteric quest or a vital component of sustainable development? Philosophical Transactions of the Royal Society of London Series B. En: Biological Sciences, No. 345, pp. 81-87. 
características más relevantes de estos dos aspectos y elabora sobre la relación entre la cuestión alimentaria, las amenazas a la biodiversidad y los nuevos problemas del derecho.

\subsection{La erosión de la biodiversidad y del conocimiento colectivo asociado}

Los recursos genéticos y el ecosistema proveen la base de nuestra alimentación y esta depende directamente del germoplasma contenido en plantas y animales que se "realiza" a través de millones de funciones que desempeñan los ecosistemas y el ambiente natural, tales como la filtración y purificación del agua, el procesamiento de nutrientes, la estabilización de la erosión y el control natural de especies que consideramos dañinas. No obstante todo esto, la seguridad que podíamos tener de que, gracias a los recursos de la biodiversidad podemos ingerir una dieta básica, no es hoy una certeza que asista a miles de millones de personas en el mundo y, probablemente menos, a las generaciones venideras.

Esta incertidumbre se deriva de un primer gran problema que caracteriza nuestro desarrollo actual y nos obliga a asumir las responsabilidades que la situación nos exige: en el curso del último siglo, hemos puesto en seria amenaza los recursos de la biodiversidad. Las necesidades e irracionalidades que imponen la supervivencia, el desarrollo y la naturaleza del progreso económico, han resultado en una aguda pérdida de la diversidad biológica. Esto se expresa, principalmente, en la explotación de los más grandes bancos de genes, las selvas tropicales, como un recurso para la mera supervivencia o como fuente de acumulación y enriquecimiento (extracción de maderas, cultivos ilícitos, obras de infraestructura, la expansión de la frontera agraria, la ampliación del latifundio, etc.) y también en razón del cambio climático producido por distintos factores pero principalmente por la base técnica y económica del patrón dominante de desarrollo.

La magnitud de la pérdida de semillas y recursos genéticos por impacto de la deforestación, la introducción de especies ajenas, la sobre-explotación de especies vegetales y animales y la contaminación, amenaza la propia supervivencia de vastos sectores de la población en diversas partes del mundo. ${ }^{28}$ Esta es una razón que se adiciona a las

\footnotetext{
${ }^{28}$ Smith y Schultes, 1990. Deforestation and Shrinking Crop Gene-pools in Amazonia. Wilson, B., 1989. Threats to Biodiversity. Scientific American No. 261. pp. 108-116. Véase también: Whitmore, T. C. y J. A. SAYER (eds.),1992. Tropical Moist Forest: Destruction and Species Extintion. En: Tropical Deforestation and Species Extinction. New York, Chapman and Hall. Consúltese también el importantísimo estudio de McNeeley, J. A.,1992. The biodiversity Crisis: Challenges for research and management, en Conservation of Biodiversity for sustainable development de O.T. Sandlund, K. Hindar y A.D. H. Brown (eds.). Oslo: Scandinavian University Press.Barbier, E. B., J. C. Burgess, y A. Markandya, 1991. The Economics of tropical deforestation. Revista AMBIO, Vol. 20, No. 2, pp. 55-58.
}

44 Jaime Bonilla-Godoy 
contradicciones que contempla la cuestión alimentaria, especialmente para los países y las masas de pobres en el mundo.

Los recursos y el conocimiento de sus propiedades y usos por parte de las comunidades nativas han sido esenciales para sopesar los problemas frecuentes de la alimentación en las distintas partes del globo. Estadísticas ampliamente conocidas basadas en datos globales de producción, dan cuenta de que solo un pequeño grupo de 12 especies cosechables (arroz, maíz, trigo, avena, sorgo, papa, caña de azúcar y soya) y 5 especies animales proveen el 75 por ciento de la alimentación mundial y la mayor cantidad de energía que los seres humanos derivan de las plantas. Los pioneros estudios de Christine y Robert Prescott-Allen sobre datos de oferta per cápita de alimentos de 146 países, encontraban en 1990 que 103 especies contribuían al $90 \%$ de la provisión de alimentos vegetales. ${ }^{29}$
Sin duda, estas cosechas tienen una inmensa importancia económica para garantizar la seguridad alimentaria. No obstante, la tendencia hacia la concentración en un pequeño número de especies - una práctica que causa la pérdida de biodiversidad-pone en tela de juicio la importancia que tiene la diversidad de especies vegetales para los propósitos de garantizar la alimentación para todos ${ }^{30}$ Basta, por ejemplo, observar las distintas variedades de vegetales que las mujeres de las áreas rurales de los países pobres ponen en cada comida para alimentar a sus hijos. Aparte de que esto refleja la tremenda importancia que juegan las campesinas pobres como guardianas de la biodiversidad y del conocimiento ancestral sobre sistemas agrícolas (agrodiversidad), lo que ellas cultivan y cosechan en sus huertas, ponen en boca de sus hijos o intercambian en los mercados locales, está principalmente basado en el uso de especies no domesticadas. Se calcula que cerca de 320 mil plantas vasculares, 3 mil especies

29 Véase al respecto, Prescott-Allen, Robert and Christine Prescott-Allen, 1990: "How Many Plants Feed the World?", Conservation Biology, Vol. 4, No. 4.

30 Diversas estimaciones precisan que, desde 1900 , se habría perdido $75 \%$ de la diversidad vegetal por el abandono de variedades locales (conocidas como "landraces") por parte de los campesinos en todo el mundo y su remplazo por variedades genéticamente uniformes y de gran productividad. El mundo solo utiliza intensivamente entre 15 y 200 especies del 4 por ciento de las 250 a 300 mil especies de plantas comestibles conocidas, y entre ellas, solo 3 (arroz, maíz y trigo) aportan cerca del 60 por ciento de las calorías y proteínas que obtenemos de las plantas. Igualmente, las mismas estimaciones señalan que 30 por ciento de especies alimenticias están expuestas a la extinción, 6 especies se pierden por mes. Véase: FAO, 1996: Global Biodiversity Assessment, y COOPER, David, 1993: "Plant Genetic Diversity and Small Farmers: Issues and Options for IFAD", Staff Working Paper 13, International Fund for Agricultural Development, Washington. 
(silvestres y domesticadas) son usadas en países pobres como alimento diario, en tanto que el número total de especies vegetales cultivadas y colectadas como insumo alimenticio excede las $7 \mathrm{mil} .^{31}$

Por otra parte, cerca de 2 de los 8.7 mil millones de hectáreas disponibles de tierra agrícola, pastos permanentes, bosques y áreas madereras se han perdido por degradación de sus ecosistemas y propiedades desde 1945. En ello han influido de manera importante la sobreexplotación de las prácticas ganaderas, la deforestación y la existencia de prácticas agrícolas inapropiadas. Mucho de esto es el resultado de la ignorancia y de la lucha de millones de pobres por sobrevivir. Pero también es el resultado directo e indirecto de los patrones de desarrollo impuestos por la búsqueda de la ganancia que caracteriza el capitalismo. En el momento actual, estas tendencias a la pérdida de tierras (de labor y de reserva natural) se adicionan al dramático déficit alimentario resultante de la pobreza, la negación de acceso a los recursos a grandes masas, la persistencia del monopolio de la tierra $\mathrm{y}$ formas tradicionales abiertamente ineficientes y de tecnología inapropiada. Un nuevo factor, el de la imposición de derechos de propiedad intelectual sobre los recursos genéticos, no hará otra cosa que agudizar esas tendencias que hacen que millones de personas sufran hambre en todo el mundo.

En estas condiciones, mientras los países en desarrollo han venido -y continúan perdiendo- gran parte de su biodiversidad en niveles dramáticos, el mundo como un todo depende crecientemente de las plantas, animales, vida microbiana y recursos fitogenéticos existente en estos países, y de los sistemas agrológicos y

\footnotetext{
31 Véase: FAO, 1996: Global Biodiversity Assessment: The State of the World's Plant Genetic Resources for Food and Agriculture, FAO, 1999: The state of food insecurity in the world food insecurity: when people must live with hunger and fear starvation. Véase también: WILKES, Garrison, 1993: "Germplasm Collections: Their Use, Potential, Social Responsibility, and Genetic Vulnerability", en International Crop Science I, Crop Science Society of America; US National Research Council Board on Agriculture, Managing Global Genetic Resources, 1993: Agricultural Crop Issues and Policies, National Academy Press, Washington; y Cooper, David, 1993: "Plant Genetic Diversity and Small Farmers: Issues and Options for IFAD", Staff Working Paper 13, International Fund for Agricultural Development, Washington. Sobre el papel de la mujer en la protección de la biodiversidad, consúltese: QUISUMBING, Agnes R. et al (1995) Women: the Key to Food Security. Food Policy Report. Washington: The International Food Policy Research Institute. FAO-WOMEN AND POPULATION DIVISIÓN, WOMEN IN DEVELOPMENT SERVICE (SDWW), 1998: Women: Users, Preservers and Managers of Agro-Biodiversity; International Plant Genetic Resources Institute IPGRI- FAO Working Group Meeting, 1996: Incorporating Gender-Sensitive Approaches into Plant Genetic Resources Conservation and Use: Background and Purpose, Roma. Véase además el reconocimiento explícito hecho en el PLAN GLOBAL DE ACCIÓN PARA LA CONSERVACIÓN Y UTILIZACIÓN SOSTENIBLE DE LOS RECURSOS GENÉTICOS VEGETALES PARA LAALIMENTACIÓNY LAAGRICULTURA(1996) de la $F A O$ que reconoce a hombres y mujeres de las comunidades indígenas y campesinas su papel de mejoradores, preservadores y conservadores de los recursos genéticos derivados de las plantas.
}

46 Jaime Bonilla-Godoy 
conocimiento asociado a su uso y conservación. ${ }^{32}$

Los informes repetidos de RAFI comisionados por la FAO y el reporte final del Taller Técnico Internacional para la sostenibilidad de la biodiversidad agrícola realizado en Roma en $1998^{33}$ insisten en que la pérdida de herencia agrícola y la creciente uniformidad genética en razón de la proliferación de semillas mejoradas controladas por las corporaciones multinacionales, constituyen una gran amenaza para los propósitos de alcanzar la seguridad alimentaria mundial. Y, de hecho, tal amenaza no tiene nada que ver con premoniciones apocalípticas. Los estudios de Vandana Shiva sobre la situación de los recursos de la biodiversidad en la India y sobre las implicaciones económicas y sociales del control de la provisión de semillas son reveladores de las tendencias que hoy son terribles afugias de los campesinos del mundo, particularmente la desposesión del conocimiento y el control de los campesinos sobre la biodiversidad, y el monopolio de semillas y prácticas agrícolas. En este punto, vale la pena transcribir algunas líneas de Shiva:
..."El Punjab fue alguna vez la más próspera región agrícola de la India. Hoy, los campesinos están desesperados y endeudados, vastas extensiones de tierra se han transformado en desiertos sedientos de agua. Y como lo señaló un viejo agricultor "aún los árboles han dejado de dar frutos debido a que el fuerte uso de pesticidas ha matado a los polinizadores -las abejas y las mariposas-. El Punjab no está solo en esta experiencia de desastre ecológico y social. El último año estuve en Warangal, en Andhra Pradesh, donde también los campesinos se estaban suicidando, agricultores que tradicionalmente cultivaban legumbres, mijo y arroz habían sido atraídos por las compañías productoras a comprar semillas híbridas de algodón que eran señaladas por los mercaderes como "oro blanco" y que supuestamente los haría millonarios. Al contrario, ellos se transformaron en mendigos. Sus semillas nativas habían sido desplazadas con nuevos híbridos que no podían ser almacenados y debían ser comprados cada año a un alto costo. Los híbridos eran también muy vulnerables a los ataques de las plagas. Los gastos en pesticidas en Warangal se incrementó en un $2000 \%$, desde 2.5 millones en 1980 a

32 Véase: Bonilla, G., Jaime y Nemogá, S. Gabriel, R., 1996: Hacia Una Estrategia en Materia de Recursos Fitogenéticos. Ponencia ante el Seminario Internacional Preparatorio de la Conferencia de la FAO sobre Recursos Fitogenéticos. UNIJUS, Universidad Nacional de Colombia. Santafé de Bogotá, mayo 1996.

33 Véase: Shand, Hope, 1997: "Human Nature: Agricultural Biodiversity and Farm-based Food Security" estudio de Rural Advancement Foundation International (RAFI) para la FAO, y FAO, 1998: Sustaining agricultural biodiversity and agro-ecosystem functions informe del International Technical Workshop, Roma organizado por el Secretariado de la Convención sobre la Diversidad Biológica y la FAO. 
50 millones en 1997. Ahora los campesinos se están comiendo los mismos pesticidas como un modo de matarse para escapar permanentemente de deudas que ya no pueden pagar. Las corporaciones están ahora tratando de introducir semillas con ingeniería genética que aumentarán aún más los costos y riesgos ecológicos...". ${ }^{34}$

Quizás esta descripción de una terrible realidad se convierta en un llamado a la reflexión sobre la incidencia dramática de las prácticas de monopolización que afectan dramáticamente la cuestión alimentaria.

\subsection{La uniformidad genética, la erosión de la diversidad y la "carrera de relevos por las variedades vegetales"}

La pérdida de la biodiversidad tiene que ver, por otra implicación, con la dinámica del desarrollo capitalista: de vieja data, la agricultura de los países industrializados -y en casi todas las demás naciones desde los cuarenta cuando se inició la revolución verde-, ha favorecido la uniformidad genética. Inmensas áreas en todo el mundo están cubiertas de monocultivos de alta productividad y de un puñado de cosechas de alta similitud genética, y los sistemas agroecológicos se basan en insumos intensivos en capital como obras y sistemas de irrigación, fertilización y pesticidas químicos que maximizan la producción.

Extensa evidencia colectada en todo el mundo muestra que la uniformidad de cosechas es el caldo de cultivo de grandes desastres, puesto que la concentración en unas pocas cosechas comerciales y prácticas similares incrementan el riesgo ante epidemias de pestes y enfermedades. Como la mayor parte de la producción comercial tiende a depender de unas pocas especies, cuando un desastre epidémico aparece, son millones de personas las que sufren las bajas de producción alimentaria. Una peste o una enfermedad se riega a gran velocidad a través de un cultivo y de allí a todos los cultivos circunvecinos. Paradójicamente, ante una situación así resultan beneficiados, vía precios de especulación o de mayor control político, aquellos que han impulsado este tipo de patrones

\footnotetext{
34 Véase, SHIVA, V.P.A., H.SCHUCKING, A., GRAY, L. LOHNMANN, y D. COOPER (edts.), 1991. Biodiversity: Social and Ecological Perspectives. New Jersey: Zed Books. SHIVA, Vandana,1995. Reductionism in Biology and its Effects on Bioethics, Biosafety and Biodiversity Erosion. En: Third World Network; SHIVA, Vandana, 1995, Why the engineering paradigm in life forms is flawed. En: Third World Resurgence, No. 53/54, Enero/Feb., pp. 25-27; SHIVA, Vandana (1996) "Jettisoning food security." Third World Resurgence, No. 67. SHIVA, Vandana, 1998: Globalización y Pobreza. En: Revista Web Mensual de Economía, Sociedad y Cultura, http://www.rcci.net/globalizacion/. Para más sobre el tópico, véase también Carta Popular para la Seguridad Alimentaria. Documento elaborado por una coalición de organizaciones populares, ONGs, sindicatos y otras entidades civiles, ambientalistas, juristas, economistas, especialistas en nutrición y seguridad alimentaria y periodistas, en un Diálogo Normativo sobre Liberalización del Comercio y Seguridad Alimentaria organizado por la Red del Tercer Mundo (India) en Delhi, 1998.
}

48 Jaime Bonilla-Godoy 
agrológicos..$^{35}$ Tipos similares de hongos, en formas aún más virulentas, son una amenaza a los cultivos de uniformidad genética de los que hoy depende el mundo y constituyen una seria amenaza a la seguridad alimentaria de quienes aún pueden demandar los productos agrícolas.

Los avances científicos recientes que permiten la modificación genética de las semillas constituyen un elemento positivo, pero las esperanzas frente a tales avances se desvanecen rápidamente cuando se sabe no solo que no existen mecanismos de bioseguridad para impedir que los organismos genéticamente modificados (OGMs) alteren la diversidad genética existente, sino que al frente de ellos está la expropiación de los recursos del tercer mundo, la apropiación y el monopolio de la experimentación y los avances científicos y, de nuevo, los mecanismos de la acumulación de capital que, como en el caso de los campesinos indios, constituyen un nuevo elemento de dominación y control de la oferta alimentaria mundial.

Para mantener la resistencia a pestes y enfermedades o para hacer más atractivas las cosechas comerciales uniformes más importantes, sus promotores han reconocido la necesidad de desarrollar otros mecanismos de protección como la tolerancia a la sequía o el mejoramiento del sabor y la forma (la homogeneidad de los productos que, como en el caso de los tomates o la papa, tanto demandan los mercados más exigentes del norte). En pos de ello y conocedores que la biodiversidad existente en el tercer mundo contiene la clave para lograr esos objetivos, pequeños contingentes de biólogos, antropólogos y botánicos recorren las comunidades campesinas en todo el mundo en búsqueda de germoplasma y de conocimiento asociado que obtienen gratuitamente (expropiación). Una vez las muestras de germoplasma y la información son colectadas, los laboratorios de mejoramiento y escaneo genético en las naciones ricas llevan a cabo el trabajo de sistematización y experimentación con infusiones frescas de genes $\mathrm{y}$, en poco tiempo, pueden manipular, en una corriente de germoplasma nuevo, exótico y útil, la composición genética de la elite de cosechas de las que depende la agricultura de esas naciones. ${ }^{36}$

35 La historia alimentaria tiene ejemplos de un dramatismo extremo sobre este tipo de eventos: la hambruna irlandesa resultante de la peste de 1840 ejemplifica claramente la preocupación por los riesgos derivados de la uniformidad genética. La variedad de papa importada durante la primera globalización desde los Andes peruanos era inmune a hongos de esta región, pero no tenía la misma resistencia frente al ataque de hongos y enfermedades propias de altas latitudes. Una vez que estos hongos atacaron, sobrevino la hambruna y la población obrera y campesina, que dependía enteramente de ese producto, quedó súbitamente sin nada que comer. El resultado más conocido fue la muerte de 1 millón y medio de personas en el curso de 5 años. Entre los menos conocidos fueron los costos de oportunidad que obtuvieron los productores ingleses de trigo y otras cosechas, la indiferencia de los círculos dominantes de Inglaterra y la utilización de la hambruna para profundizar y extender el aparato de dominación de la que resultó la actual Irlanda del Norte.

36 Véase: Correa, Carlos M., 1999: Access To Plant Genetic Resources and Intellectual Property Rights. Commission On Genetic Resources For Food And Agriculture (CGRFA) de la FAO, Background Study Paper No. 8. 
La racionalidad detrás de esta práctica, que ha sido llamada "la carrera de relevos por las variedades vegetales" entre los laboratorios mejoradores más renombrados del mundo, compañías de investigación genética, universidades y los capitales que las financian, está la enconada lucha por mantenerse un paso adelante de la amenaza de miles de pestes y enfermedades, poner a producir nuevas variedades e incrementar así el control del mercado alimentario. Esta carrera comienza con la expropiación de material genético de territorios y países, y termina en la meta de más y más beneficios económicos para la cadena productiva alimenticia, aunque el argumento que se esgrime, con algo de justicia, es que los llamados "agribusiness" de los países industrializados se estanquen y corran el riesgo de estancarse si no proceden de esta forma.

Estados Unidos estima que, sólo para dos de las principales cosechas, el acceso a germoplasma exótico proporcionaba en 1993 un valor agregado de 3200 millones de dólares a los 11000 que produce la soya cada año, y de 7000 millones a la producción anual de maíz que tenía un valor de 18000 millones. $^{37}$
Científicos italianos estiman que los beneficios de la obtención de genes raros de trigo, ascendía a 300 millones por año en ese país solamente. ${ }^{38}$ El uso de germoplasma exótico de maíz proveniente de México, el Caribe y Brasil permitió que los mejoradores norteamericanos desarrollaran una variedad comercial con resistencia a cierto gusano que producía daños a las hojas y que representaba pérdidas de 30 millones de dólares por año en el sur de ese país. ${ }^{39}$ Genes resistentes a la oxidación de una antigua variedad de girasol cultivada por los indios Havasupai del sur de Estados Unidos ya han sido incorporados en los híbridos de girasol para la producción de aceites en Australia, China, Sudáfrica, India y el propio Estados Unidos donde diversos organismos oxidantes habían llevado al abandono de la producción comercial de girasol. ${ }^{40}$

En esta carrera no sólo se buscan especies cultivables de las huertas campesinas, sino también genes de sus parientes silvestres que les resultan muy valiosas. Investigadores canadienses estiman que entre 1976 y 1980, ese tipo de especies no domesticadas aportaban, por mayor rendimiento y resistencia a

\footnotetext{
37 Véase Carta del Secretario de Estado Warren Christopher al senador George J. Mitchell del 16 de agosto de 1994, urgiéndole ratificar la Convención sobre la Biodiversidad Biológica (CBD). Citado por Shand, H., 1998. Op. Cit.

38 Véase, Shand, H. Ibid.

39 Véase: United States Department of Agriculture (USDA), "New Corn Has Resistance to Insect Pest" Comunicado de prensa, Washington, January 6, 1993.

40 Genetic Engineering News, September 15, 1993, p. 15.
} 
enfermedades, 340 millones de dólares a la economía agrícola norteamericana Mientras tanto, genes provenientes de un solo tomate silvestre recogido en Perú permitieron un incremento de 8 millones en el ingreso de los procesadores de tomate norteamericano. ${ }^{41}$ Ingenieros genetistas de la transnacional alemana Hoechst (que luego de fundirse con otras corporaciones adoptó el nombre de AgrEvo) ha desarrollado la tolerancia genética de cosechas al glifosato (el herbicida que le produce a la compañía las ventas más cuantiosas) mediante la introducción de dos genes resistentes, uno de los cuales provenía de una muestra de suelo tomada en Camerún..$^{42}$ De hecho, AgrEvo lidera el desarrollo de variedades de plantas tolerantes a los herbicidas y sus ventas de glifosato le representaban 2200 millones de dólares a esa compañía en $1994 .{ }^{43}$ No sería raro que los procesadores de cocaína en Colombia logren, aún por debajo de la mesa, acuerdos para la implementación del gene en las plantas de coca y ello representaría mejorarle su ingreso por varios miles de millones, a unos y otros.

Para el caso de la producción pecuaria, de la que depende gran parte de la dieta de los países ricos, las tendencias son similares como pueden constatarlo diversos informes conocidos a propósito de la reunión de la FAO sobre recursos genéticos. ${ }^{44}$

La erosión y expropiación de la diversidad genética, vegetal y animal, en búsqueda de mayores beneficios económicos constituyen amenazas reales a la estabilidad de la oferta global de alimentos, si es que se puede afirmar que tal estabilidad existe.

\subsection{La apropiación privada de los recursos genéticos. El derecho imperialista y las nuevas formas de dominación}

La expropiación del germoplasma y el conocimiento, el monopolio en la investigación básica en biodiversidad, el avance tecnológico reciente y la estructura de acceso, propiedad y uso nacida de la globalización, han dado origen a un nuevo haz de contradicciones que profundizan la inseguridad alimentaria: los recursos de la biodiversidad del mundo no benefician a los pueblos de los países que los poseen (los centros de biodiversidad) sino a quienes han descifrado sus componentes, propiedades $\mathrm{y}$ usos potenciales.

41 Reportado en Global Biodiversity Assessment, p. 468.

42 Referida por Shand, H. en comunicación con Michael Flitner, July 26, 1996.

43 HEISSLER, Markus. "New Style Merging: AgrEvo", en Biotechnology and Development Monitor, No. 23 (Junio 1995), p. 22.

44 Véase: HAMMOND, Keith and H.W. LEITCH, 1995: "The FAO Global Program for the Management of Farm Animal Genetic Resources, paper presented at: "Biotechnology's Role in the Genetic Improvement of Farm Animals", Beltsville, MD, (US). Para una perspectiva más amplia, véase: FAO, 1996: State of the World's Plant Genetic Resources for Food and Agriculture, Rome, 1996, p. 185. Véase también: RAFI, 1994: Occasional Paper Series, "Declaring the Benefits," Vol. 1, No. 3. Examínese también el trabajo de Shand, H. Op. Cit. 
Ese conocimiento también ha sido la base de las prácticas de innovación y experimentación científica, tecnológica y productiva que sólo un pequeño grupo de países -en rigor, un pequeño grupo de corporaciones transnacionales-, lleva a cabo. Esto se expresa claramente en el desarrollo de las multimillonarias industrias de alimentos, y se hace extensivo a los medicamentos, los productos químicos, los productos de papel, el manejo de la energía y los sectores de punta que empiezan a desarrollarse como la biomedicina y la nutricéutica (alimentos que cumplen funciones medicinales), todas ellas asentadas en las naciones ricas de hoy.

La importancia que tiene para las industrias imperialistas asegurarse el acceso legal a los recursos genéticos y para los países dominados protegerlos junto al conocimiento asociado se desprende de la práctica reciente en toda la economía mundial: el conocimiento y clasificación de usos y propiedades se ha convertido en una nueva forma de sometimiento de los países a la férula de la acumulación. Pero también, los recursos que hoy poseen los países del Sur son vitales para garantizar la seguridad alimentaria de nuestras generaciones futuras e, incluso actuales.

Las disparidades en los beneficios derivados de la utilización de los recursos de la biodiversidad y del conocimiento asociado, que calcan las tendencias del comercio de alimentos antes abordadas, resultan más grandes cuando se toma en cuenta que cerca del 90 por ciento de la diversidad biológica subsistente -y que satisface desigualmente las necesidades de la población mundial-, está localizada en las regiones tropicales y subtropicales de Asia, África y América Latina, especialmente América del Sur donde se encuentran los centros de mayor diversidad biológica del mundo ${ }^{45} \mathrm{y}$, a la vez, la mayor cantidad de personas con hambre y desnutrición.

Son los capitales corporativos de los países avanzados, principalmente de Europa y Norteamérica, los que han extraído, clasificado, analizado y utilizado industrialmente gran parte de las variedades y especies originarias de las regiones tropicales, sin que los beneficios hayan sido compartido, con sus propietarios originales y sin que su acervo natural haya servido para resolver sus problemas alimentarios. Muy por el contrario, y por estar movidos por las leyes de la acumulación y por las restricciones comerciales y de mercado a su acceso y uso, los ha empeorado.

La tendencia creciente, caracterizada por investigadores, economistas y organizaciones campesinas como una calamidad para los países del Sur, estriba

\footnotetext{
45 Véase: UNDP (United Nations Development Progamme), 1994. Conserving Indigenous Knowledge: Integrating Two Systems of Innovation. An Independent Study by the Rural Advancement Foundation International. UNDP, New York, September.
}

52 Jaime Bonilla-Godoy 
en el hecho de que las nuevas prácticas jurídicas, particularmente las relacionadas con los derechos de propiedad intelectual, permiten a las compañías mejoradoras patentar el material genético (no su conocimiento) incluso cuando las alteraciones a las estructuras genéticas de las plantas son mínimas. Después de patentadas, esas mismas compañías venden a las comunidades las semillas que ellas han usado, almacenado, conocido y cultivado por miles de años. ${ }^{46}$

La contribución de esta colección de conocimientos sobre la biodiversidad aplicada en la agricultura y salud mundiales, particularmente a las economías industrializadas, ha sido definitiva en la acumulación de riqueza en estos países. ${ }^{47} \mathrm{El}$ almacenamiento y sistematización del material genético proveniente de los países megadiversos ha dado a los países desarrollados el control y el usufructo comercial de su explotación económica. ${ }^{48} \mathrm{La}$ erosión evidente de los derechos sobre los recursos de la biodiversidad y el conocimiento asociado de las comunidades nativas ha venido presentándose como "conservación e investigación científica". Sus mecanismos han permitido el almacenamiento estratégico del material vegetal en bancos genéticos y centros de investigación que no revierten los beneficios a las comunidades aborígenes y que, en la práctica, dificultan su aprovechamiento por parte de estas poblaciones.

\footnotetext{
46 Véase: Shiva, Vandana y Radha Holla Bhar, 1997: Piracy by Patent. Publicación electrónica en URL: http//www.inetport.com. Véase también: NEMOGA, Gabriel R. (1995). Escenario de la Propiedad Industrial sobre Variedades Vegetales. En: Revista Pensamiento Jurídico No. 2. Facultad de Derecho, Ciencias Políticas y Sociales. Universidad Nacional de Colombia, Santafé de Bogotá, pp. 75-86; Bonilla, G., Jaime y Nemoga, S. Ricardo (1996): La Globalización de la Economía, el Abismo tecnológico y el Papel de las Naciones Pobres. Una Mirada a la Biodiversidad desde la Economía Política. UNIJUS, Universidad Nacional de Colombia. Publicado en: Biodiversidad y Derechos de los Pueblos. Amazonía por la Vida. Acción Ecológica. Quito, Ecuador, 1996. De los mismos autores, véase: "Propiedad intelectual y el control de los recursos de la biodiversidad" En: Revista Deslinde, No. 22, diciembre 1997. CEDETRABAJO, Bogotá.

47 Véase: Barbier, E. B., J. C. Burgess, y C. Folke, 1994. Paradise Lost? The Ecological Economics of Biodiversity. London: Earthscan Publications. Brown, K. D., D. PEARCE, C. PERRINGS, y T. SWANSON. Economics and the Conservation of biological diversity. Working Paper No. 2. Global Environment Facility. NORGAARD, R. B. 1988. The rise of the global exchange economy and the loss of biological diversity. En: E.O. Wilson (de.). Washington, D.C: National Academy Press. ROSE, R., 1992. Economic Aspects of conserving biological diversity. En: Agricultural and Resources Quarterly, Vol. 4, No. 3. pp. 378-388. SOLBRIG, O.T., 1993. Biodiversity and Economics. En: Revista INTERCIENCIA, Vol. 18, No. 3. SWANEY, J.A. y P.I. OLSON, 1992. The economics of biodiversity lives and lofestyles. En: Journal of Economic Issues, Vol. 16, No. 1. pp. 1-25. TISDELL. C., 1990. Economics and the Debate about preservation of species, crop varieties and genetic diversity. En: Ecological Economics, No. 2.

48 Cerca del 70 por ciento de todas las semillas recolectadas en los países subdesarrollados permanece almacenada en los centros de investigación, instituciones y laboratorios privados o en los centros de investigación (IARC) con sede en los países industrializados, y más del 85 por ciento de las colecciones microbiales ex situ (levaduras, bacterias, hongos) permanecen almacenados en los bancos genéticos de los mismos paises. Véase: UNDP (United Nations Development Progamme). Conserving Indigenous Knowledge: Integrating Two Systems of Innovation. An Independent Study by the Rural Advancement Foundation International. UNDP, New York, September, 1994.
} 
La diversidad y el conocimiento de sistemas agrícolas y agroalimentarios de los países pobres enfrentan la erosión de sus derechos sobre los recursos genéticos frente a los emporios comerciales de los países imperialistas. Las comunidades nativas han probado y desarrollado muchas especies en sus propias tierras y mares convirtiéndose, mediante prácticas sistemáticas y dinámicas, en los mejores conocedores de sus características, usos y formas de conservación. En el nuevo derecho y prácticas comerciales, el costo real de cientos de años de trabajo y acumulación de conocimiento local y el mejoramiento gradual y constante de semilla que hacen los campesinos nunca se reconoce ni tampoco se retribuye. $\mathrm{La}$ devolución de recursos tomados gratuitamente (o expropiados) de los países pobres en forma de mercancía es la práctica de piratería más evidente que llevan a cabo las compañías que hoy se apropian y monopolizan los bienes comunes, los recursos y el conocimiento asociado.

Los gobiernos de Estados Unidos y Europa presionan permanentemente en las negociaciones internacionales (GATT y OMC) para que los países adopten una legislación que proteja los derechos de propiedad intelectual (TRIPS, por sus siglas en lengua inglesa) a las compañías mejoradoras de recursos. Estados Unidos ha emprendido, por ejemplo, varios procesos jurídicos y sanciones políticas y económicas a la India que, hasta 1997 , no había adoptado una legislación para la protección de patentes de propiedad intelectual. En sus reclamos, ese país exigía en 1998 una indemnización por 200 millones de dólares al año como pérdidas que supuestamente tenían las compañías norteamericanas por regalías no pagadas. Los estudios de Rural Advancement Fund International (RAFI) sugieren que, si se aplica efectivamente esa racionalidad, el trabajo de mejoramiento vegetal llevado a cabo por campesinos del tercer mundo durante miles de años, junto al descubrimiento y sistematización de su uso alimenticio o medicinal obligaría que Estados Unidos debería pagar unos 300 millones al año como regalías a las comunidades campesinas por el uso de alimentos que hoy se venden en los supermercados norteamericanos, y cerca de 5 mil millones de dólares por el uso de fármacos vendidos anualmente en las droguerías de ese país.

La monopolización de los recursos conlleva no sólo la pérdida de la independencia alimentaria de campesinos en todo el mundo que han desarrollado prácticas de mejoramiento $o$ descubrimiento de especies vegetales y animales y pesticidas naturales. Las comunidades nativas pierden también cada vez más el control del material genético que, por siglos, domesticaron, obtuvieron, mejoraron y compartieron, y que les ha servido para su propia supervivencia, alimentación y salud.

Adicionalmente, se registra una evidente expropiación mediante títulos de propiedad intelectual obtenidos por quienes usufructuando los logros de los sistemas cooperativo-colectivos de innovación de las comunidades nativas, 
consolidan patentes y secretos industriales en amplios campos de innovación (desarrollos biotecnológicos que incluyen productos y procesos químicos $\mathrm{y}$ farmacéuticos, fertilizantes, mejoramiento de semillas, aislamiento de componentes medicinales o nutricéuticos de plantas y animales, etc.). Cada vez son mayores las denuncias relacionadas con instituciones y corporaciones multinacionales del Norte que, habiendo obtenido patentes sobre ciertos desarrollos con recursos biológicos extraídos de las áreas megadiversas, no sólo se niegan a pagar regalías o compensaciones a los países y comunidades de origen, sino que los revenden bajo nuevas formas o contenidos mejorados, derivando ganancias exorbitantes. ${ }^{49}$

Todo esto significa una terrible contradicción en relación con la cuestión de la seguridad alimentaria y una nueva amenaza a la posibilidad de que todos los seres humanos puedan acceder a sus alimentos básicos. Si las tendencias y prácticas actuales de apropiación se fortalecen aún más, como parece sugerir la lógica de la globalización, la mayoría de los pueblos del mundo tendrán que pagar a las compañías agroalimentarias y corporaciones transnacionales por el acceso a semillas y productos que una vez fueron su propiedad y les garantizó su seguridad alimentaria.

De este modo, en torno a los beneficios de la biodiversidad en general, y su papel fundamental en proveer de alimentos a los pobres y hambrientos del mundo, se contraponen dos tendencias. De un lado, los sistemas institucionales de innovación que dominan la ciencia y tecnología modernas de Occidente conceden derechos casi ilimitados a los individuos y las corporaciones para monopolizar no sólo inventos, sino también descubrimientos sobre los componentes de la biodiversidad y sobre la variedad de sistemas agrícolas y agroalimentarios practicados, en forma sistemática, en todos los lugares del mundo. Con este propósito, los sistemas de patentes y secretos industriales, surgidos originalmente para conceder derechos sobre partes y procesos creados por los inventores de herramientas, máquinas y procesos técnicos, hoy se han extendido

49 Al respecto, puede consultarse información que muestra la gravedad del problema. Véase: Barett, S., 1994. The Biodiversity supergame. En: Environment and Resource Economics, Vol. 4, No. 1. pp. 111-122; Mendelson, R., 1994. Property Rights and tropical deforestation, Oxford Economic Papers, No. 46, pp. 750-756; Sedjo, R. A., 1988. Property Rights and the protection of plant genetic resources, en; Seeds and Sovereignty: The Use and Control of Plant Genetic Resources, de J.R. Kloppenburg (editor); Sedjo, R. A., 1992. Property Rights, genetic resources and biotechnological change. En: Journal of Law and Economics, No. 35, pp. 199-213; SIMPSON, R. D. y R. A. Sedjo, 1993. The Commercialization of indigenous genetic resources: Values, institutions, and instruments. Resources for the Future. Mimeo.; SWANSON, T.J. (editor), 1994. Intellectual Property Rights and Biological Conser vation: A Multidisciplinary Analysis. Cambridge: Cambridge University Press; Wallace, L. T., J. Moles, y K. Rodriguez, 1993. Proceedings of the panel discussion on Property Rights. University of California, Berkeley, Dept. of Agricultural and Resource Economics Working Paper No. 678, junio; Bonilla G., Jaime y Nemogá, S. Gabriel, 2000: Biodiversidad, Economía y Derecho. en Politeía, Revista de la Facultad de Derecho, Ciencias Políticas y Sociales, Universidad Nacional de Colombia. No. 25. 
para otorgar monopolios legales sobre procedimientos y materia viva. Por el otro lado, los pueblos de las naciones ricas en diversidad y las comunidades indígenas y campesinas pobres que han preservado y sistematizado el conocimiento de sus recursos conciben la extensión e imposición de semejante lógica y de sus imperativos jurídico-económicos como una plaga terrible que hay que atacar colectivamente.

\section{La geoeconomía mundial del hambre}

\section{A manera de conclusiones}

Este artículo ha presentado una primera constatación de que, gracias a los enormes logros tecnológicos y productivos que hoy ha alcanzado la humanidad, el mundo actual está en capacidad de producir lo suficiente para satisfacer las necesidades alimentarias de todos. Sin embargo, se ha argumentado que la naturaleza del régimen de acumulación y la dinámica del capital, principalmente de las naciones ricas y de las clases dominantes en los países pobres, impiden que ello sea una realidad y que, en cambio, la producción alimentaria esté controlada por ese pequeño puñado de países y clases, y que sea deficitaria para la mayoría de los pueblos. La discusión propuesta por este artículo permite, entonces, enunciar algunas conclusiones importantes sobre las contradicciones que, iteradas por el proceso de globalización, caracterizan el panorama de la cuestión alimentaria: a) El papel y los cambios en la agricultura, operados por el proceso de la globalización, han venido redefiniendo el carácter, función y estructura de los sectores productivos de las economías semicoloniales, las prioridades en cuanto a su desarrollo y sus relaciones con los países que controlan los circuitos globales de acumulación. Esta redefinición ha profundizado las disparidades productivas, la pérdida de la autonomía y autosuficiencia, el recurso a las importaciones masivas y la exasperación del problema alimentario en la mayoría de las economías;

b) El control de la producción por parte de los capitales y corporaciones de las naciones ricas está en la base del aumento de la pobreza, la miseria, el desempleo y del abismo en la distribución doméstica e internacional de la riqueza. La continua reducción del ingreso de las mayorías, a su vez, constituye el principal factor que provoca la contracción de la demanda de alimentos básicos y el incremento de la inseguridad alimentaria a niveles más dramáticos de los que hoy tenemos;

c) El estancamiento de la agricultura en los países pobres resultante de la reestructuración neoliberal, especialmente de la agricultura campesina, la reducción dramática del ingreso de las mayorías y el recurso a las importaciones de alimentos, emergen como factores de ampliación del abismo entre quienes pueden ingerir una dieta mínima y los que no pueden lograrlo, como ha ocurrido a lo largo de toda América Latina durante 
los años noventa. ${ }^{50}$ A lo largo del África Subsahariana, el sur de Asia y América Latina y el Caribe, es muy improbable que la paridad oferta-demanda se alcance a través de más y más importaciones de alimentos. Por otra parte, la disminución e inestabilidad del ingreso, el bajo crecimiento, la exigua capacidad de compra, los ajuste de la balanza comercial y un volátil comportamiento del mercado mundial de productos provenientes de las regiones atrasadas han hecho que, durante los noventa, las crecientes importaciones de alimentos sólo hayan alcanzado para cubrir las necesidades de las capas medias y altas, las únicas que pueden generar una demanda más o menos rentable para las corporaciones y sectores que están a la cabeza del negocio de alimentos. Esa realidad que hemos presenciado en los noventa implica mayor diferenciación social y mayor exclusión de extensos sectores de la población a la oferta alimentaria;

d) Las tendencias de la producción, comercio y experimentación mundial, especialmente las relacionadas con la apropiación de la biodiversidad y la imposición de derechos de propiedad intelectual sobre recursos genéricos, controladas por los países ricos a través de los acuerdos comerciales del GATT, primero, y recientemente de la OMC concitan hoy resistencia en todos los foros mundiales. A pesar del creciente rechazo de las masas del mundo contra la globalización, la preeminencia de tales tendencias no parece apuntar hacia transformaciones radicales en la actual división internacional del trabajo y la inequidad en la distribución de la riqueza mundial y con menor razón en el campo de la provisión de alimentos. Mientras el orden económico y político mundiales continúen dominados por las leyes de la acumulación del capital, en las que destacan la voracidad dinámica del capital financiero y de las corporaciones transnacionales, es difícil pensar que los intereses de acumulación se concilien con los intereses de los millones de hambrientos por todo el mundo.

e) Las comunidades y pueblos comparten un sentido de responsabilidad comunal por su territorio y recursos, y conciben que el uso de recursos de la biodiversidad, las prácticas agrícolas y agroalimentarias y el conocimiento asociado a los recursos deben usarse para el beneficio de todos, especialmente de quienes sufren el hambre. Sin lugar a dudas, la expansión de las formas de monopolio sobre los recursos genéticos y la apropiación privada del conocimiento colectivo tienen nefastas implicaciones para la preservación del conocimiento indígena $\mathrm{y}$ de las comunidades que los han creado $^{51}$

${ }_{50}$ Véase al respecto, Bonilla-Godoy, J. Op. Cit.

51 Agencias como The National Institutes of Health $(\mathrm{NIH})$ de los Estados Unidos y otras instituciones similares han venido presionando para que se apruebe la concesión de patentes sobre genes humanos o sobre fragmentos de ADN del cerebro humano. La pretensión de obtener patentes sobre genes y fragmentos aislados, sin conocerse aún su uso o propósito potencial, hace pensar que, de convertirse en norma, cualquier cosa que se encuentre en el ecosistema podrá ser objeto de monopolio legal simplemente asumiendo que puede llegar a tener una utilidad, aún si ésta no ha sido identificada. Con este enfoque, las grandes compañías están ya listas a solicitar patentes sobre grandes cantidades de especies que previamente no estaban documentadas. 
y para mejorar la situación alimentaria de nuestros países. El monopolio de todas las formas de vida oficializado a través de los TRIPS constituye una nueva característica inaceptable de la voracidad que implica la acumulación capitalista y que debe ser, lo mismo que el monopolio de la producción y comercio de productos agrícolas, combatido decididamente por todos los pueblos de los países pobres. ${ }^{52}$

En el nivel global, la inseguridad alimentaria y la pobreza que está en su base no parecen que vaya a disminuir considerablemente en el futuro inmediato dadas las tendencias de la globalización. Con los mejores pronósticos de inversión en investigación, en redistribución de la tierra y demás recursos, en tecnología y en política de apoyo en los productores pobres y medios en todas las naciones sería posible reducir el número de personas hambrientas de 800 a 650 millones en el año 2010. Asia del Este y Asia del Sur mejorarían sustancialmente gracias a su desempeño exportador y a la mayor importación de alimentos. ${ }^{53}$ En el África Subsahariana, África del Norte y América Latina y el Caribe, sin embargo, el número de personas pobres y subalimentadas seguramente crecerá y esto también es inaceptable.

La diferencia entre producción y consumo local de alimentos se ampliará durante los años venideros a lo largo de los países atrasados. Solamente la diferencia entre producción y demanda de cereales en el África Subsahariana se triplicará hasta 27 millones de toneladas en el año 2020. Gracias a su evolución reciente y una vez recobrada de la crisis, Asia del Este se convertirá en el mayor importador de alimentos en el año 2020, seguido por el norte de África y el Oriente Medio, los cuales podrán adquirir alimentos con los ingresos del petróleo. Según las proyecciones hechas desde 1988, las importaciones netas del África Subsahariana para 2010 crecerán 330 por ciento y, aparte de la cuantiosa ayuda que hoy reciben -principalmente con viejos sobrantes almacenados en Europa o Norteamérica-, aún no es claro de dónde provendrán los recursos para pagar esas importaciones pues la carencia de divisas para comprarlas no parece resolverse en el corto plazo.$^{54} \mathrm{El}$ citado pronóstico del IFPRI señala que... "los niveles de tecnología y conocimiento existentes no

\footnotetext{
52 Sobre la naturaleza del nuevo derecho de apropiación regulado por los Derechos de Propiedad Intelectual Relativos al Comercio (TRIPS, por sus siglas en inglés), véase: Nemogá, Ricardo. De la apropiación a la expropiación. En: Semillas no.5. Octubre 1995; Hunter, D., Sommer, J. y Vaughan, S., 1995. Concepts and Principles of International Law: An Introduction. Serie de Documentos Environment and Trade, 2., publicados por UNEP-Ginebra. Véase: http://www.unep.ch/ en el World Wide Web, y Hadson, T., F. Englander, and H. O'Keefe. 1995. Rain forest preservation, markets, and medicinal plants: Property rights and land value issues. En: Conservation Biology.

53 Véase al respecto: Pinstrup-Andersen \& Rajul Pandya-Lorch, (1996): The World Food Situation And 2020 Vision. Food Policy Research Institute (IFPRI), Washington, D. C. USA.

54 Sobre estos problemas y proyecciones, véase: World Bank, 1992, IFPRI, 1996, Op. cit y FAO, 2000. Op. Cit.
}

58 Jaime Bonilla-Godoy 
permitirán la producción de toda la comida requerida en el año 2020 y más allá... y que...."sólo para el año 2008 el mismo número de personas, 1.2 billones, podría estar viviendo con menos de 1 dólar diario".
Desde cualquier punto de vista que se le quiera mirar, esta situación es completamente inaceptable y es tarea de todos atacar las causas que la generan. Ojalá que esta sea también la convicción de mis lectores.

\section{Bibliografía}

AMERICAN SOCIETY OF AGRONOMY, SOIL SCIENCE SOCIETY OF AMERICA, (1993): Intellectual property rights: protection of plant materials, CSSA Special Publication No. 21, Madison CSSA.

Chauvet, M. (1994). "Los flancos expuestos de la seguridad nacional: la soberanía alimentaria y la bioseguridad", en Sociológica. Año 9, Núm. 25, mayo-agosto. Departamento de Sociología (UAM-Azcapotzalco), México. pp. 231-214.

Falcón, W. P. (1991). "El papel de los Estados Unidos en la reducción del hambre en el mundo", en Carl K. Eicher y John M. Staatz (comp.), Desarrollo agrícola en el Tercer Mundo. Fondo de Cultura Económica, México. pp. 219-234.

Garrido, L. J. (1997). “La crítica del neoliberalismo realmente existente”, en Noam Chomsky y H. Dieterich, La sociedad global. Educación, mercado y democracia. Ed. Joaquín Mortiz, México.pp. 7-14.

Gioia, Vincent, (1997), "Plant Patents - R.I.P.”, Journal of the Patent \& Trademark Office Society (JPOS), July 1997.

González Rubí, R. (1991). "Sección latinoamericana”, en Comercio Exterior. Vol. 41, No. 6, junio. Bancomext, México. pp. 558-562.

González Vigil, F. et al. (1988). Alimentos y trasnacionales. Centro de Estudios y Promoción del Desarrollo, Lima, Perú.

Green, R. (1989). "El comercio agroalimentario mundial y las estrategias de las trasnacionales", en Comercio Exterior, Vol. 39, Núm. 8, agosto. Bancomext, México. pp. 663-673.

Gugerell, Christian (1996), "The European experience” in Le génie génétique. Biotechnology and patent law, Perret at al (eds.), CEDIDAC, Lausanne. 
Heitz, André, (1991), “Genetic Resources and Plant Breeders' Rights”, Seminar on the Nature of and Rationale for the Protection of Plant Varieties under the UPOV Convention, Buenos Aires.

Hope, Shand, (1997). "Human Nature: Agricultural Biodiversity and Farm-based Food Security", an independent study prepared by the Rural Advancement Foundation International (RAFI) for the Food and Agriculture Organization of the United Nations.

Houser, David (1993), "Exemptions under patents and certificates covering plants and comments on material transfer agreements", in CSSA (1993).

IFPRI (International Food Policy Research Institute). 1995. A 2020 vision for food, agriculture, and the environment: The vision, challenge, and recommended action. IFPRI, Washington, D. C. (draft).

León, A. y Guzmán, E. (1997). "Soberanía y heterogeneidad: tres décadas de financiamiento a la agricultura europea", en Cuadernos agrarios, nueva época, Núm.15, enero-junio. México. pp. 161-178.

Lesser, W., (1998), Sustainable Use of Genetic Resources under the Convention on Biological Diversity, Cab International, Wallingford-New York.

Llambí, L. (1993). "Reestructuración mundial y sistemas agroalimentarios. Necesidad de nuevos enfoques", en Comercio Exterior, Vol. 43, Núm. 3, marzo. Bancomext, México. pp. 257-264

Macer, Darryl, (1990) Shaping Genes. Erhics, Law and Science of Using Genetic Technology in Medicine and agriculture, Eubios Ethics Institute, New Zealand.

Mergers, Robert y Nelson, Robert, (1996), "The Complex Economies of Patent Scope", in The sources of economic growth, Harvard University Press, Cambridge.

Miranda, Santos, M. and Lewontin, R. (1997), "Genetics, plant breeding and patents: conceptual contradictions and practical problems in protecting biological innovations", Plant Genetic

Mooney, Pat Roy, (1998), "The Parts of Life. Agricultural Biodiversity, Indigenous Knowledge, and the Role of the Third System", Development Dialogue, Special Issue, Uppsala.

Murdoch, W. (1984). La pobreza de las naciones. Fondo de Cultura Económica, México.

Neff, Richard and Smallson, Fran, (1994), NAFTA. Protecting and Enforcing Intellectual Property Rights in North America, Shepard's, Colorado.

Okuyama, Shoichi, (1997), "New JPO Guidelines for Biotech Inventions - Focus on Disclosure Required and Claims Allowed", Patents \& Licensing, June.

60 Jaime Bonilla-Godoy 
Osorio, R. (1984). “Informe Kissinger”, en Análisis de la Economía Latinoamericana y los Estados Unidos, marzo-septiembre. IIEC, México.

Pantoja, E. (1987). “El traspatio productivo de los EEUU”, en Nueva Sociedad, Núm. 89, mayojunio. Caracas. pp. 61-68.

Paulino, Leonardo. 1986. Food in the Third World: Past trends and projections to 2000. Research Report 52. Washington, D. C.: International Food Policy Research Institute.

Pinstrup-Andersen \& Rajul Pandya-Lorch, (1996): The World Food Situation And 2020 Vision. Food Policy Research Institute (IFPRI), Washington, D.C. USA. Agroalimentaria No. 2. Junio.

Plowman, R. D., (1993), "Intellectual Property Protection of Plants - The Agricultural Research Service Perspective", in Crop Science Society of America, Resources Newsletter, No. 112, International Plant Genetic Resources Institute (IPGRI), Rome.

Roberts, Tim, (1996), “Patenting Plants Around the World”, EIPR, No. 10.

Rosegrant, Mark W., and Mark Svendsen. 1993. Asian food production in the 1990s: Irrigation investment and management policy. Food Policy (February): 13-32.

Rosegrant, Mark W.; Mercedita Agcaoili-Sombilla, and Nicostrato D. Pérez. 1995. Global food projections to 2020: Implications for investment. Washington, D. C.: International Food Policy Research Institute.

Rubio, B. (1995). “La vía agroexportadora-neoliberal en América Latina y el nuevo orden agrícola internacional”, en Alejandro Encinas (Coord.), El campo mexicano en el umbral del siglo XXI. Espasa Calpe Hoy, México. pp. 185-221.

Salis, Annette, 1995: Cultivos Andinos y Seguridad Alimentaria. ¿Qué Política?

Seay, Nicholas, (1993), "Intellectual Property Rights in Plants", in Crop Science Society of America, American Society of Agronomy, Soil Science Society of America, Intellectual property rights: protection of plant materials, CSSA Special Publication N 21.

Shiva, Vandana and Holla-Bhar, Radha, (1996), "Piracy by Patent: The Case of the Neem Tree", in MANDER, Jerry y GOLDSMITH Edward (Eds.), The Case Against the Global Economy and for a.

Tribble, Jack, (1995), “Gene Ownership versus Access: Meeting the Needs”, NABC Report 7. Genes for the Future: Discovery, Ownership, Access, New York.

Taylor, Roger, (1997), "The pitfalls of functional claims", Managing Intellectual Property. June. 
Tyers, Rod. 1994. Economic reform in Europe and the former Soviet Union: Implications for international food markets. Research Report 99. Washington, D. C.: International Food Policy Research Institute.

UN ACC/SCN (United Nations Administrative Committee on Coordination-Subcommittee on Nutrition). 1992. Second report on the world nutrition situation, Vol. 1, Global and regional results. Geneva: UN ACC/SCN.

UNCTAD (1996), The TRIPS Agreement and Developing Countries, United Nations Conference on Trade and Development, New York and Geneva.

UNEP, (1996), The impact of intellectual property rights systems on the conservation and sustainable use of biological diversity and on the equitable sharing of benefits from its use.

USDA: United States Departament of Agriculture (1994). Grain: Work Markets and Trade, april. Washington, D. C.

62 Jaime Bonilla-Godoy 
Anexo No. 1

Cuadro A-6

América Latina y el Caribe: Desempleo Urbano

(Tasas anuales medias)

\begin{tabular}{|c|c|c|c|c|c|c|c|c|c|c|}
\hline & 1980 & 1985 & 1990 & 1992 & 1993 & 1994 & 1995 & 1996 & 1997 & $1998 a /$ \\
\hline $\begin{array}{l}\text { América Latina } \\
\text { y el Caribe } \\
\text { Argentina }\end{array}$ & 6.2 & 7.3 & 5.9 & 6.2 & 6.2 & 6.3 & 7.2 & 7.7 & 7.3 & 8.0 \\
\hline $\begin{array}{l}\text { Areas Urbanas b/ } \\
\text { Barbados }\end{array}$ & 2.6 & 6.1 & 7.4 & 7.0 & 9.6 & 11.5 & 17.5 & 17.2 & 14.9 & 12.9 \\
\hline $\begin{array}{l}\text { Total nacional c/ } \\
\text { Bolivia }\end{array}$ & - & - & 14.7 & 23.0 & 24.3 & 21.9 & 19.7 & 14.3 & 12.2 & 11.8 \\
\hline $\begin{array}{l}\text { Capitales Depmentls. } \\
\text { Brasil }\end{array}$ & - & 5.8 & 7.3 & 5.4 & 5.8 & 3.1 & 3.6 & 3.8 & 4.4 & - \\
\hline $\begin{array}{l}\text { Seis áreas metropol. } \\
\text { Chile }\end{array}$ & 6.3 & 5.3 & 4.3 & 5.8 & 5.4 & 5.1 & 4.6 & 5.4 & 5.7 & 7.6 \\
\hline $\begin{array}{l}\text { Total nacional d/ } \\
\text { Colombia c/ }\end{array}$ & 10.4 & 15.3 & 7.8 & 6.7 & 6.5 & 7.8 & 7.4 & 6.4 & 6.1 & 6.4 \\
\hline $\begin{array}{l}\text { Siete áreas metropol. } \\
\text { Costa Rica }\end{array}$ & 10.0 & 13.9 & 10.5 & 10.2 & 8.6 & 8.9 & 8.8 & 11.2 & 12.4 & 15.3 \\
\hline $\begin{array}{l}\text { Total urbano } \\
\text { Cuba }\end{array}$ & 6.0 & 6.7 & 5.4 & 4.3 & 4.0 & 4.3 & 5.7 & 6.6 & 5.9 & 5.4 \\
\hline $\begin{array}{l}\text { Total nacional } \\
\text { Ecuador } \mathrm{c} /\end{array}$ & - & - & - & 6.1 & 6.2 & 6.7 & 7.9 & 7.6 & 6.8 & 6.5 \\
\hline $\begin{array}{l}\text { Total urbano } \\
\text { El Salvador }\end{array}$ & 5.7 & 10.4 & 6.1 & 8.9 & 8.9 & 7.8 & 7.7 & 10.4 & 9.3 & 11.5 \\
\hline $\begin{array}{l}\text { Total urbano } \\
\text { Guatemala e/ }\end{array}$ & - & - & 10.0 & 8.2 & 8.1 & 7.0 & 7.0 & 7.5 & 7.5 & 7.9 \\
\hline $\begin{array}{l}\text { Total nacional } \\
\text { Honduras }\end{array}$ & 2.2 & 12.1 & 6.0 & 1.5 & 2.5 & 3.3 & 3.7 & 3.7 & 5.0 & 5.9 \\
\hline $\begin{array}{l}\text { Total urbano } \\
\text { Jamaica } \mathrm{c} /\end{array}$ & 8.8 & 11.7 & 7.8 & 6.0 & 7.0 & 4.0 & 5.6 & 6.5 & 6.4 & 5.2 \\
\hline $\begin{array}{l}\text { Total nacional } \\
\text { México }\end{array}$ & - & - & 15.3 & 15.7 & 16.3 & 15.4 & 16.2 & 16.0 & 16.5 & 15.5 \\
\hline $\begin{array}{l}\text { Areas urbanas b/ } \\
\text { Nicaragua }\end{array}$ & 4.5 & 4.4 & 2.7 & 2.8 & 3.4 & 3.7 & 6.2 & 5.5 & 3.7 & 3.2 \\
\hline $\begin{array}{l}\text { Total nacional } \\
\text { Panamá c/ }\end{array}$ & - & 3.2 & 7.6 & 14.4 & 17.8 & 17.1 & 16.9 & 16.0 & 14.3 & 12.2 \\
\hline $\begin{array}{l}\text { Región metropolitana } \\
\text { Paraguay }\end{array}$ & 9.9 & 15.6 & 20.0 & 17.5 & 15.6 & 16.0 & 16.6 & 16.9 & 15.4 & 15.0 \\
\hline $\begin{array}{l}\text { Asunción metropol. f/ } \\
\text { Perú }\end{array}$ & 4.1 & 5.2 & 6.6 & 5.3 & 5.1 & 4.4 & 5.3 & 8.2 & 6.9 & 7.2 \\
\hline $\begin{array}{l}\text { Lima metropol. } \\
\text { República Dominicana c/ }\end{array}$ & 7.1 & 10.1 & 8.3 & 9.4 & 9.9 & 8.8 & 8.2 & 8.0 & 9.2 & 8.4 \\
\hline $\begin{array}{l}\text { Total nacional } \\
\text { Trinidad y Tobago }\end{array}$ & - & - & - & 20.3 & 19.9 & 16.0 & 15.8 & 16.5 & 15.9 & 14.3 \\
\hline $\begin{array}{l}\text { Total nacional } \\
\text { Uruguay }\end{array}$ & - & - & 20.1 & 19.7 & 19.8 & 18.4 & 17.2 & 16.3 & 15.0 & 14.2 \\
\hline $\begin{array}{l}\text { Total urbano g/ } \\
\text { Venezuela }\end{array}$ & - & - & 8.5 & 9.0 & 8.3 & 9.2 & 10.3 & 11.9 & 11.5 & 10.1 \\
\hline Total nacional & 6.0 & 13.1 & 10.4 & 7.8 & 6.6 & 8.7 & 10.3 & 11.8 & 11.4 & 11.2 \\
\hline
\end{tabular}

Fuente: (CEPAL - Sobre la base de cifras oficiales.

a/ Cifras preliminares. b/ Representa un alto y creciente número de áreas urbanas. c/ Incluye el desempleo oculto. d/ La cifra de la columna para 1985 corresponde a 1984. e/ Estimaciones oficiales. f/ Desde 1994, las cifras corresponden al total urbano. g/ En 1980 y 1985, las cifras corresponden a Montevideo. 
Anexo No. 2

Gráfico I. 12b

América Latina y el Caribe: Desempleo Urbano

(Porcentaje de la población económicamente activa, primer semestre de cada año)

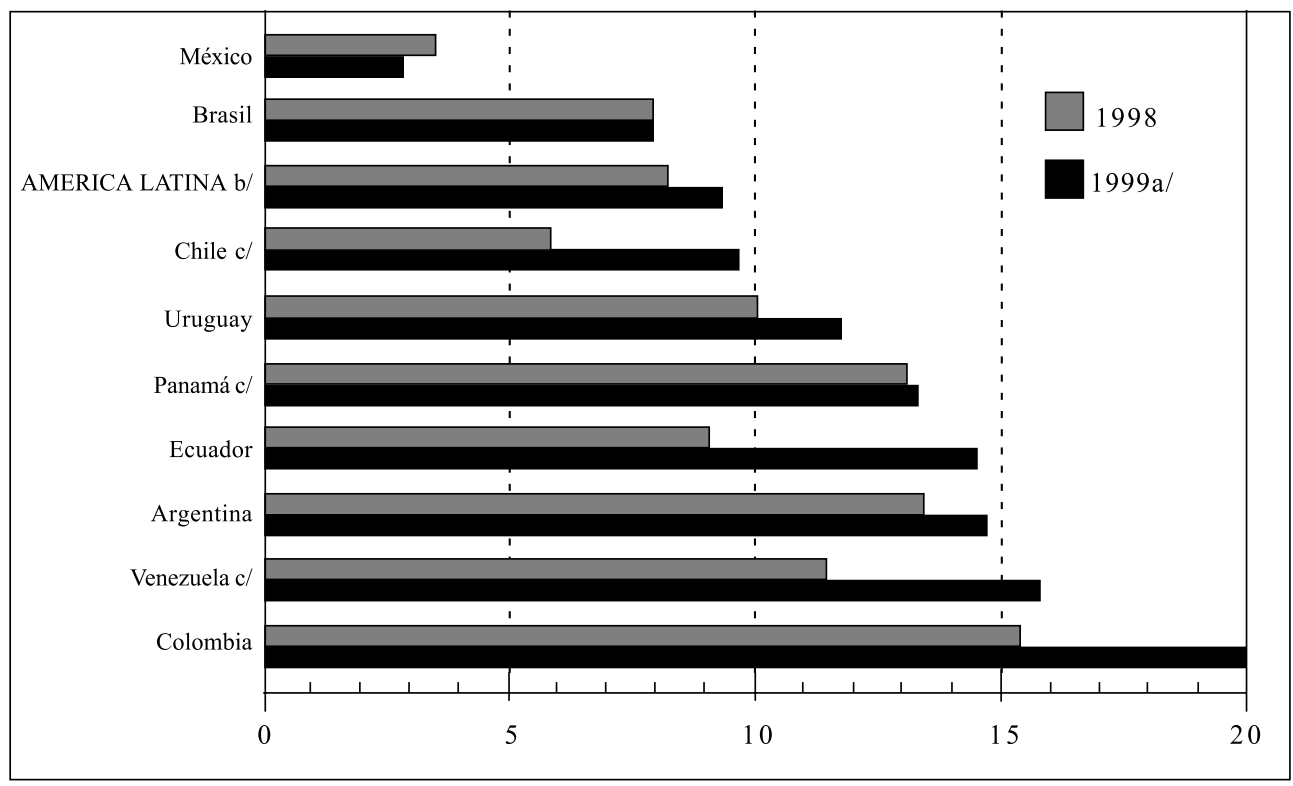

Fuente: CEPAL - Sobre la base de cifras oficiales.

a/ Cifras preliminares

b/ Promedio ponderado

c/ Cobertura nacional

64 Jaime Bonilla-Godoy 
Anexo No. 3

Tendencias del desarrollo económico de América Latina y el Caribe en el largo tiempo y comparación con las grandes regiones del mundo.

Crecimiento Anual Promedio entre 1965 y 1998 (\%)

\begin{tabular}{|c|c|c|c|c|c|c|c|c|c|c|}
\hline \multirow[b]{2}{*}{ País } & \multicolumn{2}{|c|}{$\begin{array}{c}\text { Producto } \\
\text { Interno Bruto }\end{array}$} & \multicolumn{2}{|c|}{ Población } & \multicolumn{3}{|c|}{$\begin{array}{c}\text { Valor } \\
\text { Agregado }\end{array}$} & \multirow[b]{2}{*}{$\begin{array}{c}\text { Consumo } \\
\text { Privado }\end{array}$} & \multirow[b]{2}{*}{$\begin{array}{c}\text { Inversión } \\
\text { Domés- } \\
\text { tica Fija }\end{array}$} & \multirow{2}{*}{$\begin{array}{c}\text { Exporta- } \\
\text { ción de } \\
\text { bienes y } \\
\text { servicios }\end{array}$} \\
\hline & Total & $\begin{array}{c}\text { Per } \\
\text { Cápita }\end{array}$ & Total & $\begin{array}{l}\text { Fuerza } \\
\text { de } \\
\text { trabajo }\end{array}$ & $\begin{array}{c}\text { Agri- } \\
\text { cultura }\end{array}$ & $\begin{array}{c}\text { Indus- } \\
\text { tria }\end{array}$ & $\begin{array}{c}\text { Servi- } \\
\text { cios }\end{array}$ & & & \\
\hline Argentina & 1.9 & 0.4 & 1.5 & 1.5 & 1.6 & 1.1 & 2.6 & 2.4 & 1.0 & 5.2 \\
\hline Bolivia & - & - & 2.3 & 2.4 & - & - & - & 2.4 & 2.1 & 3.0 \\
\hline Brasil & 4.3 & 2.2 & 2.0 & 2.9 & 3.4 & 4.5 & 4.9 & 4.4 & 1.7 & 8.3 \\
\hline Chile & 3.6 & 1.9 & 1.7 & 2.3 & 3.5 & 3.2 & 4.9 & 3.3 & 4.8 & 8.3 \\
\hline China & 8.6 & 6.8 & 1.7 & 2.1 & 4.1 & 10.9 & 9.3 & 7.4 & 9.9 & 13.5 \\
\hline Colombia & 4.2 & 2.0 & 2.2 & 3.2 & 2.7 & 4.5 & 5.0 & 4.1 & 4.6 & 5.7 \\
\hline Costa Rica & 4.0 & 1.2 & 2.7 & 3.5 & 3.2 & 4.7 & 4.1 & 3.2 & 4.8 & 7.0 \\
\hline Cuba & - & - & 1.1 & 2.1 & - & - & - & - & - & - \\
\hline Ecuador & 4.6 & 1.8 & 2.6 & 3.0 & 3.5 & 6.1 & 4.6 & 4.2 & 3.1 & 7.2 \\
\hline El Salvador & 1.5 & -0.4 & 2.1 & 2.8 & 0.6 & 0.7 & 2.2 & 1.9 & 2.6 & 1.3 \\
\hline Guatemala & 3.4 & 0.7 & 2.6 & 2.8 & 2.8 & 3.6 & 3.5 & 3.3 & 2.5 & 2.4 \\
\hline Haití & 1.1 & -0.8 & 1.9 & 1.2 & 0.2 & 1.3 & 1.6 & 1.8 & 8.6 & 4.3 \\
\hline Honduras & 3.8 & 0.6 & 3.1 & 3.3 & 2.6 & 4.4 & 4.4 & 3.7 & 4.0 & 2.6 \\
\hline Jamaica & 0.8 & -0.4 & 1.2 & 1.9 & 0.9 & 0.1 & 1.9 & 1.3 & -0.1 & 1.9 \\
\hline México & 3.9 & 1.5 & 2.4 & 3.3 & 2.1 & 4.1 & 4.2 & 3.7 & 3.6 & 10.0 \\
\hline Nicaragua & -0.4 & -3.3 & 3.0 & 3.6 & 0.0 & -0.1 & -0.2 & -0.8 & 0.6 & 0.8 \\
\hline Panamá & 3.0 & 0.7 & 2.3 & 2.9 & 2.1 & 2.5 & 2.5 & 4.4 & 4.3 & -0.1 \\
\hline Paraguay & 5.3 & 2.3 & 2.8 & 3.0 & 4.4 & 5.8 & 5.4 & 5.8 & 7.0 & 8.8 \\
\hline Perú & 2.1 & -0.3 & 2.3 & 2.9 & 1.7 & 2.2 & 2.1 & 2.0 & 2.6 & 2.0 \\
\hline Puerto Rico & 2.9 & 1.6 & 1.2 & 2.0 & 1.7 & 4.3 & 3.3 & 2.9 & 0.4 & 4.4 \\
\hline Trinidad \& Tobago & 3.7 & 2.6 & 1.1 & 2.0 & -2.0 & 0.1 & 2.4 & 3.3 & - & 4.0 \\
\hline Uruguay & 1.8 & 1.2 & 0.6 & 1.0 & 1.5 & 1.2 & 2.4 & 1.7 & 2.0 & 5.9 \\
\hline Venezuela & 2.0 & -0.8 & 2.8 & 3.7 & 2.7 & 1.6 & 2.7 & 2.4 & 1.2 & 2.0 \\
\hline Total Mundo & 3.2 & & 1.4 & 1.7 & & 2.0 & & 2.3 & & .. \\
\hline Países Bajos Ingresos & 5.9 & 3.7 & 2.1 & 2.2 & 3.3 & 7.8 & 6.5 & 5.3 & 7.0 & 7.0 \\
\hline Excl. China e India & 4.3 & 1.7 & 2.5 & 2.5 & 2.8 & 5.7 & 5.1 & 4.2 & 4.0 & 4.3 \\
\hline Países Ingreso Medio & 3.7 & 1.9 & 1.7 & 1.9 & 2.3 & 2.9 & 3.9 & - & 2.6 & 6.1 \\
\hline Ingreso Medio Bajo & - & - & 1.6 & 1.7 & - & - & - & - & - & - \\
\hline Ingreso Medio Alto & 4.2 & 2.2 & 1.9 & 2.3 & 2.4 & 3.6 & 4.2 & - & 3.6 & 8.4 \\
\hline Ingreso Medio y Bajo & 4.2 & 2.2 & 2.0 & 2.1 & 2.9 & 4.3 & 4.6 & 4.1 & 3.7 & 5.6 \\
\hline Sur Asia Pacífico & 7.5 & 5.7 & 1.8 & 2.2 & 3.6 & 9.9 & 7.9 & 6.7 & 9.8 & 10.5 \\
\hline Europa y Asia Central & - & - & 0.8 & 0.9 & - & - & - & - & - & - \\
\hline $\begin{array}{l}\text { América Latina y } \\
\text { el Caribe } \\
\text { Medio Oriente y }\end{array}$ & 3.5 & 1.3 & 2.1 & 2.8 & 2.6 & 3.2 & 3.9 & 3.5 & 1.8 & 5.9 \\
\hline norte de África & 3.1 & 0.2 & 2.8 & 2.8 & 4.2 & 1.3 & 4.1 & - & - & - \\
\hline Sur de Asia & 4.9 & 2.7 & 2.2 & 2.1 & 2.9 & 5.5 & 5.7 & 4.5 & 5.2 & 7.2 \\
\hline África Subsahariana & 2.6 & -0.3 & 2.7 & 2.5 & 1.9 & 2.5 & 3.1 & 2.7 & 0.0 & 2.5 \\
\hline Países Altos Ingresos & 3.0 & 2.3 & 0.7 & 1.1 & - & - & - & 3.2 & 3.0 & 5.7 \\
\hline Europa & - & - & 0.4 & 0.7 & - & - & - & - & - & 5.4 \\
\hline
\end{tabular}

Fuente: The World Bank Grupo, 2000. 
66 Jaime Bonilla-Godoy 